\title{
Signalling Pinpointed to the Tip: The Complex Regulatory Network That Allows Pollen Tube Growth
}

\author{
Patricia Scholz *, Jannis Anstatt, Hannah Elisa Krawczyk and Till Ischebeck * \\ Department of Plant Biochemistry, Albrecht-von-Haller-Institute for Plant Sciences and Goettingen Center for \\ Molecular Biosciences (GZMB), University of Goettingen, Justus-von-Liebig Weg 11, D-37077 Goettingen, \\ Germany; jannis.anstatt@stud.uni-goettingen.de (J.A.); hannah.krawczyk@uni-goettingen.de (H.E.K.) \\ * Correspondence: patricia.scholz@uni-goettingen.de (P.S.); tischeb@uni-goettingen.de (T.I.); \\ Tel.: +49-(0)-551-3928648 (P.S. \& T.I.); Fax: +49-(0)-551-3925749 (P.S. \& T.I.)
}

Received: 16 June 2020; Accepted: 23 August 2020; Published: 26 August 2020

\begin{abstract}
Plants display a complex life cycle, alternating between haploid and diploid generations. During fertilisation, the haploid sperm cells are delivered to the female gametophyte by pollen tubes, specialised structures elongating by tip growth, which is based on an equilibrium between cell wall-reinforcing processes and turgor-driven expansion. One important factor of this equilibrium is the rate of pectin secretion mediated and regulated by factors including the exocyst complex and small $G$ proteins. Critically important are also non-proteinaceous molecules comprising protons, calcium ions, reactive oxygen species (ROS), and signalling lipids. Among the latter, phosphatidylinositol 4,5-bisphosphate and the kinases involved in its formation have been assigned important functions. The negatively charged headgroup of this lipid serves as an interaction point at the apical plasma membrane for partners such as the exocyst complex, thereby polarising the cell and its secretion processes. Another important signalling lipid is phosphatidic acid (PA), that can either be formed by the combination of phospholipases $C$ and diacylglycerol kinases or by phospholipases D. It further fine-tunes pollen tube growth, for example by regulating ROS formation. How the individual signalling cues are intertwined or how external guidance cues are integrated to facilitate directional growth remain open questions.
\end{abstract}

Keywords: pollen tube; phosphoinositides; small G proteins; reactive oxygen species; phosphatidic acid; lipid signalling; cell wall; secretion; exocyst complex

\section{Introduction}

Pollen are the male microgametophytes of seed plants, part of the short haploid phase in the life cycle of the spermatophytes. In angiosperms, the microgametophyte consists of one vegetative cell and two sperm cells formed from a generative cell, either during pollen development or later during fertilisation. After contact of the pollen grain with a compatible stigma, the vegetative cell forms a pollen tube that grows through the style to the ovule to transport the inherently non-motile sperm cells to the embryo sac [1,2]. There, the pollen tube ruptures and releases the sperm cells for double fertilisation, which concludes the gametophytic phase of the angiosperm life cycle [3-5].

Growth of the angiosperm pollen tube relies on extreme polarisation of the vegetative cell. Massive secretion of new cell wall material takes place at the very tip of the pollen tube, which exclusively extends into one direction. This extreme form of polarised cell expansion is called tip growth and occurs in plant pollen tubes as well as in plant root hairs [6,7]. The tip growth of pollen tubes reaches considerable growth rates in the range of $0.1 \mu \mathrm{m} / \mathrm{s}$ in vitro and $1 \mu \mathrm{m} / \mathrm{s}$ in vivo. Pollen tubes are thus among the fastest growing cells in the plant world [8]. The enhanced growth rate of angiosperm pollen tubes is thought to be a key factor contributing to the dominance of angiosperms in land plants 
today [9]. On the other hand, it poses significant challenges to cell organisation, cell wall integrity, secretion, and signalling networks regulating the complex process of tip growth.

\section{Pectin Is an Important Component of the Pollen Tube Cell Wall}

Pollen tube tip growth is based on a delicate equilibrium between secretion of cell wall material at the pollen tube tip and turgor-driven cell expansion. The maintenance of this equilibrium and concurrent preservation of the pollen tube's shape sets special demand for the cell wall and its components. Modelling approaches demonstrated that a gradient in cell wall stiffness is required to sustain proper pollen tube shape [10-13]. This gradient changes from the more flexible apical tip towards the stiff pollen tube shank [13-15]. The cell wall component best suited to provide this gradient is pectin, a polymer characterised by its backbone containing galacturonan $[12,16]$. Pectin is synthesised in the Golgi apparatus and subsequently transported and secreted via secretory vesicles [17]. The apically secreted pectin is initially in an esterified state, as the carboxyl groups of the secreted galacturonan are linked to methoxy groups $[16,18,19]$. The esterified pectin is very flexible, allowing turgor-driven expansion. Upon cleavage of the ester bonds, pectin chains are cross-linked by $\mathrm{Ca}^{2+}$ ions, thus changing the rheological properties of the pectic compounds to increased stiffness $[20,21]$. Together with increasing abundance of cellulose and callose in the cell wall of the pollen tube shank, this leads to increased cell wall stiffness and stabilises the distal pollen tube cell wall. This results in a cell wall that resists the turgor and maintains the cylindrical shape of the pollen tube $[14,22,23]$. The transition from methylesterified "soft" pectin to de-esterified pectin occurs in the subapical region [14,19]. The enzymes responsible for this transition are pectin methylesterases (PMEs), that cleave the ester bonds in the secreted galacturonan monomers, enabling $\mathrm{Ca}^{2+}$-crosslinking of the pectin chains [24]. Lack of PME activity frequently leads to impaired pollen tube growth, visible in decreased growth rate and pollen tube length [20,25-27]. PMEs and pectin are transported in the same secretory vesicles and are subsequently secreted at the tip of the pollen tube. Consequently, the enzymatic activity has to be controlled to prevent premature de-esterification. According to protein structure type I and type II, PMEs are distinguished that also differ in their regulation mechanism [28,29]. In type II PMEs, premature enzyme activity and de-esterification of pectin is prevented by proteinaceous pectin methylesterase inhibitors (PMEIs) that form 1:1 complexes with the enzyme [30]. For type I PMEs, it is assumed that a protein-inherent pro-region acts as an auto-inhibitor during transport, as this pro-region shows significant homology to PMEIs $[28,29,31]$. The activation of type I PMEs requires the cleavage of the pro-region, and mature PMEs purified from the cell wall lack this domain [31]. However, where and how this cleavage occurs is still unclear. Activation of type II PMEs on the other hand can be achieved by the removal of PMEIs from the apoplast, which is attained by the endocytic uptake of the PMEIs in the subapical region of the pollen tube [32].

\section{Pectin Secretion during Pollen Tube Growth}

Providing enough pectin at the apical tip to maintain the fast growth rates of pollen tubes requires abundant secretion of cell wall material. Hence, exocytic vesicles fuse at a high rate with the pollen tube plasma membrane in the tip regions, providing signalling molecules as well as cell wall and membrane material [12,33-35]. Abundant endocytic processes balance exocytosis, which serves at least two functions: Firstly, to take up regulatory molecules from the apoplast, e.g., PMEI proteins, and secondly, to internalise surplus membrane material. Due to the higher surface-to-volume ratio of the delivered secretory vesicles, more membrane lipids than required fuse with the plasma membrane. These excess phospholipids are at least partially recycled back by the budding of endocytic vesicles [32,36-38]. The exact localisation of the exo- and endo-cytic processes is a matter of debate, that shall not be discussed here but has been examined elsewhere [6,39].

The precedence of endocytic and exocytic processes in the growing region of the pollen tube, aka the tip, is mirrored in the pollen tube's subcellular structure (Figure 1). Growing angiosperm pollen tubes exhibit a pronounced zonation of the cytoplasm $[33,40]$. The apex of the growing tube 
is packed with secretory vesicles and lacks organelles, effecting a "clear zone" in light microscopy imaging [41-43]. The concentration of vesicles is maintained by F-actin structures, most visible in the form of the "actin fringe" in the subapical region adjacent to the clear zone [41]. This subapical region is organelle-rich and forms the transition between growing tip and non-growing shank-region of the pollen tube. The shank can be divided into the proximal and the distal end, the latter of which is highly vacuolated in older pollen tubes and separated by callose plugs from the actively streaming cytoplasmic shank region [34]. The proximal shank region is organelle-rich, containing, i.a., the male germ unit of the two sperm cells and the vegetative nucleus, which is transported on microtubules maintaining a constant distance to the pollen tube tip [44]. Additionally, endoplasmic reticulum (ER) and Golgi apparatus are present, which produce the contents of the secretory vesicles accumulating at the pollen tube tip. The movement of these organelles and their vesicles towards the apex strongly relies on actin structures. Throughout the shank, strong cortical and central actin bundles serve as tracks for associated myosins and their cargos. It is speculated that the actin fringe then serves as a filter that withholds the organelles in the subapical region and allows only vesicles to pass to the apex $[8,41]$. The transport of membranous organelles in the pollen tube of angiosperms follows a "reverse fountain" pattern: Organelles and exocytic vesicles are transported in anterograde direction to the tip close to the cell membrane, while retrograde transport occurs along central actin cables. The typical actin structure and the "reverse fountain" streaming pattern immanently lead to the V-shape of the clear zone at the apex, also termed inverted cone [42,44].

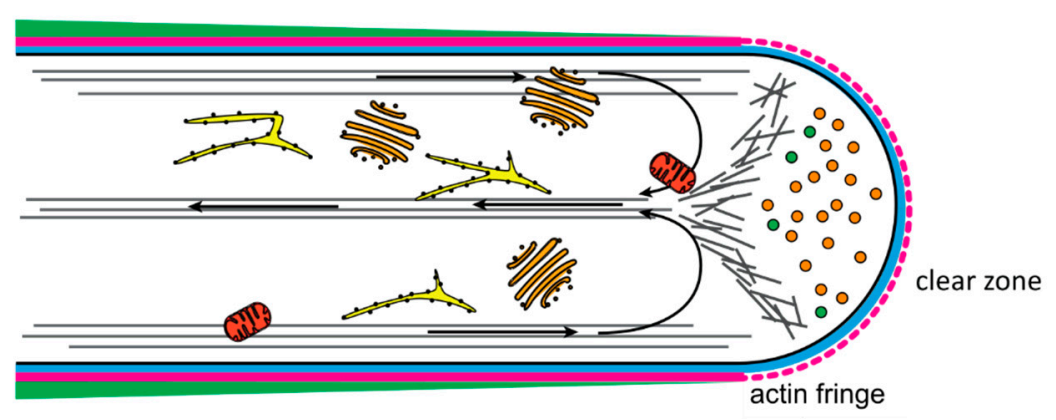

\author{
callose \\ cellulose \\ de-esterifed pectin \\ esterifed pectin
}

Figure 1. Tip-growing pollen tubes require a distinct subcellular organisation. The abundant secretion processes at the pollen tube tip lead to a distinct structuration in growing pollen tubes. The apex of the growing tube is packed with secretory vesicles and void of organelles leading to a V-shaped "clear zone". It is speculated that the organelles are prevented from entering that zone by the cortical actin structure of the actin fringe. Behind the actin fringe, F-actin forms strong actin bundles required for transport processes. Vesicles and organelles, like mitochondria (depicted in red), endoplasmic reticulum (yellow), and Golgi (orange) structures, are transported on cortical actin bundles towards the tip. Retrograde transport takes place on central actin cables, resulting in a "reverse fountain" pattern of cellular transport. Additional structuration can be observed in the pollen tube cell wall. Esterified pectins predominantly form the cell wall at the pollen tube tip, although the presence of cellulose has been reported in some cases. Further back, cellulose and callose are embedded in a pectin matrix of de-esterified pectin monomers crosslinked with $\mathrm{Ca} 2+$ ions, leading to increased stiffness of the shank cell wall.

\title{
4. Pollen Tube Growth Is Regulated by Several Interwoven Signalling Networks
}

The equilibrium between the cell's turgor and the secretion of pectin has to be accurately balanced to maintain proper tip growth [6], and the pollen tube must be able to redirect its growth direction in response to external guidance cues [45]. Consequently, a plethora of signalling networks and factors are involved in the regulation of pollen tube growth, including ion gradients, small GTPases, reactive oxygen species (ROS) (Figure 2), and signalling phospholipids [7,39,46-51]. A further layer of complexity is added by the cross-talk between the different signalling networks: GTPase activity 
influences the pollen tube inherent calcium gradient and relies on phosphoinositides for downstream signalling, while phosphoinositides influence the regulators of GTPases [52-54]. This leads in vitro to interdependent oscillations of GTPase activity, secretion, the $\mathrm{Ca}^{2+}$ gradient, and the growth rate observable, e.g., in lily or tobacco pollen tubes [55-59].

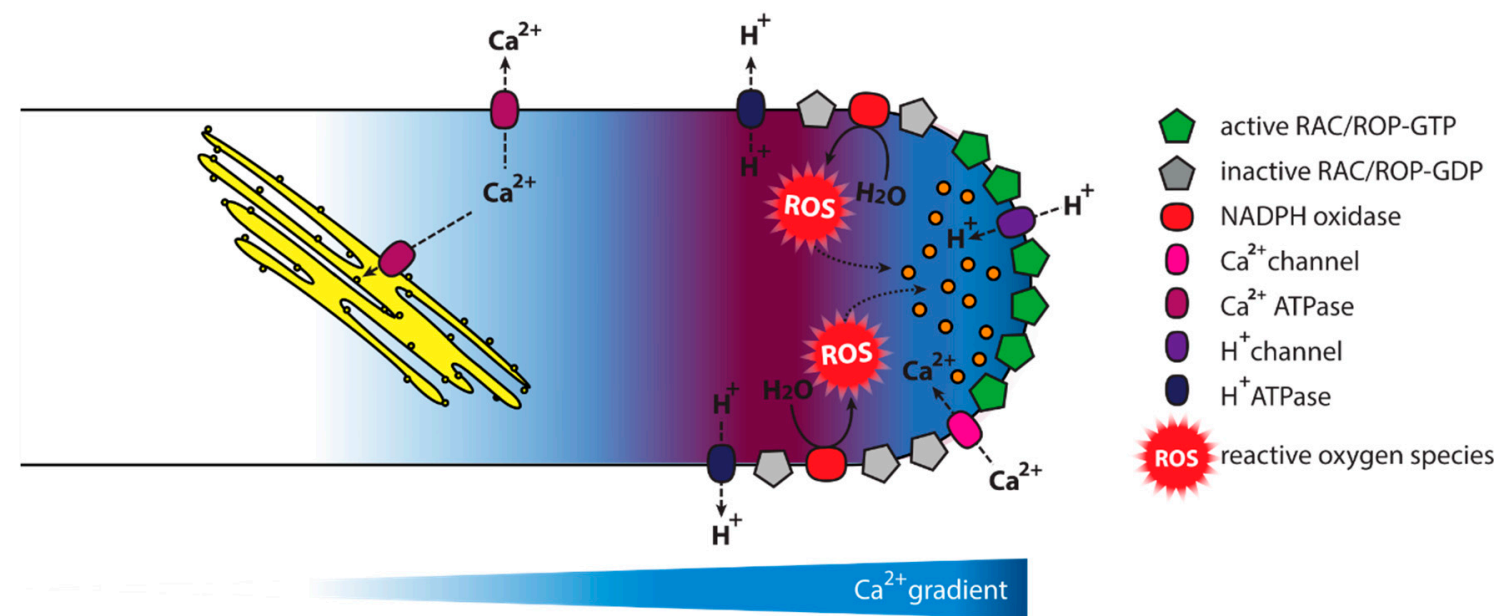

alkaline banc

Figure 2. A complex signalling network is involved in pollen tube growth. Pollen tube growth is controlled by a variety of signalling factors, including ions, reactive oxygen species (ROS), and small Rop/Rac-GTPases cycling between active and inactive states. Furthermore, different phosphoinositides and derived lipids are involved in pollen tube growth regulation (See Figures 3 and 4).

\section{Reactive Oxygen Species in Pollen Tube Growth}

ROS are vital signalling molecules during fertilisation, as they control stable pollen tube growth but also induce rupture of the tube at the end of its life cycle [51,60]. First indications on the role of ROS in pollen tube growth came from studies on the tobacco NADPH oxidase (NtNOX) [61]. NOX activity is confined to the plasma membrane and accumulation of ROS at the pollen tube tip could be visualised by dihydrofluorescein diacetate or nitroblue tetrazolium staining. Furthermore, inhibition of NOX activity disturbs pollen tube growth [61,62]. ROS production was also observed in lily, pear, kiwi, Picea meyeri, or olive pollen tubes [63-67]. In Arabidopsis, the two respiratory burst oxidase homolog (Rboh) genes, AtRBOHH and AtRBOHJ, are expressed in pollen tubes, where their encoded proteins localise to the apical plasma membrane. AtRBOHH and AtRBOHJ are enzymatically active in a $\mathrm{Ca}^{2+}$-dependent manner and pollen tube growth in the double mutant rbohH rbohJ is impaired [68]. Additional investigation of the rbohH rbohJ double mutant revealed higher amplitudes in growth rate oscillations and a tendency to burst prematurely. It was consequently proposed that AtRBOHH and AtRBOHJ serve as "speed control", to allow coordination of cell expansion and deposition of new cell wall material [69]. This model was later extended, describing AtRBOHH and AtRBOHJ as part of a cell wall integrity-controlling pathway in pollen tube growth [50,70]. There, they are proposed as downstream effectors of a complex of receptor-like kinases (RLKs) [70-72], which responds to autocrine signalling peptides of the rapid alkalinization factor (RALF) family $[4,35,71]$. RALF4 and RALF19 act redundantly in the maintenance of pollen tube integrity as they influence the deposition of callose and pectins in the growing pollen tubes [35]. Pollen tubes of the double mutant ralf4 ralf19 burst prematurely, likely due to their involvement in the secretion of cell wall material [4]. RALF4/19 interact with the Catharanthus roseus receptor-like kinase 1-like (CrRLK1L) receptors BUDDHA'S PAPER SEAL (AtBUPS) 1/2 and ANXUR (AtANX) 1/2, of which AtANX1/2 were shown to act upstream of AtRBOHH and AtRBOHJ [70]. Furthermore, addition of RALF4 led to increased ROS production in in vitro grown pollen tubes [71]. Another member of the RALF family, RALF 34, might play an antagonistic role to 
RALF4/19. RALF34 is predominantly expressed in mature ovules and its addition to pollen tubes grown in vitro induces pollen tube rupture [4]. Like RALF4/19, RALF34 is able to bind to ANX1/2 and BUPS1/2 and was proposed to outcompete RALF4/19 after the pollen tube reaches the ovule, thereby inducing pollen tube rupture [4,73]. Interestingly, pollen tube rupture and sperm release was also connected to high ROS concentrations in the filiform apparatus [60]; however, a direct connection between RALF signalling and ROS production by the female gametophyte has not been described so far.

Another described source of ROS in pollen tubes is oxidation of the polyamine spermidine catalysed by a polyamine oxidase [74,75]. Loss of polyamine oxidase activity leads to shorter pollen tubes and the tip localisation of its polyamine substrates seems to be important for physiological tip growth $[75,76]$. ROS signals are integrated into other signalling networks during pollen tube growth, including signalling phospholipids, small GTPases, and ion gradients $[62,68,77,78]$. For example, AtRBOHD triggered by abscisic acid (ABA) in stomatal closure has been shown to bind to the lipid phosphatidic acid, and phosphatidic acid increases ROS production [79]. Also, $\mathrm{Ca}^{2+}$ has been proposed to act both up- and down-stream of ROS signals, activating RBOH enzymes, whose ROS products could in turn trigger $\mathrm{Ca}^{2+}$-influx from the apoplast in a positive feedback loop $[68,80]$.

\section{Ion Gradients in Growing Pollen Tubes}

Among ions, $\mathrm{Ca}^{2+}$ and $\mathrm{H}^{+}$have been most closely linked to pollen tube growth regulation. In lily pollen tubes, a pH-zonation from the acidic tip towards an alkaline band at the base of the clear zone was described [81]. A similar $\mathrm{pH}$ gradient changing with growth rate oscillations was also observed in pollen tubes of tobacco and has been linked to the shank-localised, proton-exporting $\mathrm{H}^{+}$-ATPase NtAHA $[82,83]$. The role of $\mathrm{H}^{+}$ions in the regulation of tube growth remains unclear though-initial studies on the $\mathrm{pH}$ gradient in Lilium longiflorum concluded that protons are not central to growth regulation [84]. However, later studies described a connection between $\mathrm{pH}$ and actin organisation during tube growth [85]. Additionally, reversible inhibition of pollen tube growth in lily using potassium cyanide $(\mathrm{KCN})$ leads to a sharp decline of the $\mathrm{pH}$ gradient, and the alkaline band was the first ion gradient to be re-established after removal of the inhibitor [86]. A study on Arabidopsis pollen tubes connected intracellular $\mathrm{pH}$ changes with anion transport over the pollen tube membrane, hypothesising that protons might be part of a network reacting to $\gamma$-aminobutyric acid (GABA)-mediated signalling [87]. Further observations were made in a recent study on an Arabidopsis triple mutant lacking the three autoinhibited plasma membrane proton $\left(\mathrm{H}^{+}\right)$ATPase $(\mathrm{AHA})$ isoforms, AtAHA6, AtAHA8, and AtAHA9 [88]. AHA6, AHA8, and AHA9 are predominantly expressed in pollen and pollen tubes and pollen of the triple mutant aha6 aha $a$ aha 9 shows reduced germination rates, while germinated pollen tubes grow slower and tend to stop prematurely. AHA6, AHA8, and AHA9 localised to different extents in the plasma membrane of the pollen tube shank. There, they are thought to pump protons out of the pollen tube's cytoplasm, thereby establishing a proton gradient from the tip towards the shank. Consequently, the cytoplasm of pollen tubes from the triple mutant aha6 aha8 aha9 is more acidic and the $\mathrm{pH}$ gradient is strongly decreased. Further analysis of the mutant pollen tubes also revealed a decreased anion efflux from the pollen tube, a decreased membrane potential, and changes in the actin organisation, underlining the importance of proton transport across the pollen tube membrane [88].

The importance of $\mathrm{Ca}^{2+}$ for pollen germination and subsequent pollen tube growth has already been reported more than 50 years ago for more than 80 plant species [89]. Furthermore, the interaction between pollen tubes and the female gametophyte before double fertilisation is also accompanied by distinct $\mathrm{Ca}^{2+}$ dynamics in synergids, egg, and central cell $[90,91]$. In terms of pollen tube growth, it has been observed that growth rate oscillations and oscillations of the $\mathrm{Ca}^{2+}$ gradient depend on each other in vitro $[92,93]$. The $\mathrm{Ca}^{2+}$ gradient in the cytosol of growing pollen tubes is formed with peak concentrations close to the apical plasma membrane. The exact localisation of the peak $\mathrm{Ca}^{2+}$ concentration determines growth orientation $[93,94]$. Exact $\mathrm{Ca}^{2+}$ concentrations in the pollen tube 
vary considerably between reports, depending on the methods used [95]. At the tip, values are in the range of 0.1 to $10 \mu \mathrm{M}$, while for the shank, values around $0.02-0.2 \mu \mathrm{M}$ have been reported $[49,95,96]$. Reports agree though, that the $\mathrm{Ca}^{2+}$ gradient is only observable in growing pollen tubes [95]. Irrespective of the actual values, the high apical concentration of $\mathrm{Ca}^{2+}$ is likely established by an influx of $\mathrm{Ca}^{2+}$ from the apoplast, as the application of calcium chelators and calcium channel inhibitors leads to the dissipation of the $\mathrm{Ca}^{2+}$ gradient $[97,98]$. Different $\mathrm{Ca}^{2+}$ channels at the tip of the pollen tube are one requirement and regulation point for a $\mathrm{Ca}^{2+}$ gradient [99-102]. In this context, Arabinogalactan proteins in the apoplast might play a role, acting in a feedback loop that couples $\mathrm{Ca}^{2+}$-influx and secretion with the physical strain at the pollen tube tip during cell wall extension [103]. Secondly, a mechanism for the efflux of $\mathrm{Ca}^{2+}$ in tip-neighbouring regions is required. This $\mathrm{Ca}^{2+}$ efflux occurs via PM- and possibly also ER-localised $\mathrm{Ca}^{2+}$-ATPases, transporting the ions out of the cell or into the endomembrane system, respectively $[96,104,105]$.

Calcium could play a direct role in secretion by triggering exocytosis, as has been shown in neurons, where a calcium influx rapidly triggers the soluble $N$-ethylmaleimide-sensitive-factor attachment receptor (SNARE)-mediated vesicle fusion of neurotransmitter-filled vesicles with the plasma membrane. The transmitting of the $\mathrm{Ca}^{2+}$ signal is thought to occur via the two synaptic proteins Synaptotagmin-1 and Complexin, which interact with SNARE proteins on vesicles and the presynaptic membrane in a partially assembled state $[106,107]$. Interestingly, Soluble NSF attachment protein 25 (SNAP-25), a protein of the SNARE complex, was in turn reported to control voltage-gated $\mathrm{Ca}^{2+}$ channels and $\mathrm{Ca}^{2+}$ concentrations in the presynaptic cell [108]. While this process serves as an example that $\mathrm{Ca}^{2+}$ might directly influence secretion, it is unclear if $\mathrm{Ca}^{2+}$ in pollen tubes would act similarly, as secretory vesicles with cell wall material are unlikely to be in a similar "clamped" state of a partially assembled SNARE complex.

Furthermore, detection of $\mathrm{Ca}^{2+}$ occurs via sensor proteins, like calcium-dependent protein kinases (CDPKs). CDPKs possess a regulatory $\mathrm{Ca}^{2+}$-binding domain, and upon $\mathrm{Ca}^{2+}$-binding, the protein kinase catalytic domain is activated, so they act as "sensor responders" $[49,109]$. CDPK proteins involved in pollen tube growth have been reported for Arabidopsis, maize, and petunia [110-112], and CDPK activity has been linked to the adjustment of ion fluxes across the plasma membrane [113-116]. Other $\mathrm{Ca}^{2+}$ sensor proteins include calmodulin, calmodulin-like proteins, and calcineurin B-proteins that act as "sensor relays" transmitting the $\mathrm{Ca}^{2+}$ signal via altered protein-protein interactions. Several of these sensor relays have been described in connection with tube growth, actin organisation, and regulation of $\mathrm{K}^{+}$transmembrane transport [117-121]. $\mathrm{Ca}^{2+}$-mediated stabilisation and destabilisation of actin filaments could also play a role in establishing actin structure, as high $\mathrm{Ca}^{2+}$ concentrations cause disassembly of filamentous actin, acting via actin-binding proteins [122]. This regulation of actin structure connects $\mathrm{Ca}^{2+}$ to another signalling factor as $\mathrm{Ca}^{2+}$-dependent F-actin modulation is one of two downstream pathways of the Arabidopsis Rop/Rac GTPase Rop1 [52].

\section{Small GTPases Define the Pollen Tube Tip}

The impact of small GTPases on tip-growing cells has been discussed in several recent reviews, therefore we will only briefly mention their basic roles and functions in pollen tube growth here $[39,48,123,124]$. Small monomeric GTPases (ca. $21 \mathrm{kDa}$ ) serve as molecular switches, cycling between an active GTP-bound state and an inactive GDP-bound state [125]. They are regulated by further proteins like guanine nucleotide exchange factors (GEFs), GTPase activating proteins (GAPs), and guanine nucleotide dissociation inhibitors (GDIs). GEFs activate small GTPases by exchanging GDP against GTP, while GAPs activate the intrinsically low GTPase activity of the monomeric GTPases [126,127]. GDIs modify subcellular localisation of small GTPases as they are able to remove the prenylated GTPases from the membrane and sequester them in the cytoplasm [128].

The superfamily of small GTPases is further divided into different GTPase families, i.a., the Raband the Rho-family [129]. Proteins of the Rab-GTPase family are involved in intracellular membrane 
trafficking during pollen tube growth, regulating vesicle transport between Golgi apparatus and ER or from the Golgi apparatus to the plasma membrane [130,131]. In Arabidopsis, the Rab-GTPase AtRabA4d is tip-localised and regulates vesicle trafficking, and its absence causes male-specific transmission defects [132]. Arabidopsis pollen tube growth is also impaired in null mutants of AtRabD2b and AtRab2c [133]. Importantly, Rab function relies on geranylgeranylation, and mutations of the Rab geranylgeranyl transferase inhibits normal pollen and pollen tube development, similar to mutations of the Rab proteins themselves [134]. In addition to the Rab-GTPase family, GTPases of the Rop/Rac protein family are involved in tip growth of pollen tubes. Active Rop-GTPases are locally confined to the pollen tube tip, thus providing a molecular marker for polarised secretion $[54,135,136]$. There, they can interact indirectly with the exocyst subunit Sec3, which determines polar secretion during pollen tube growth [137-139]. Furthermore, Rop-GTPases participate in the transduction of external signals like guidance cues, the organisation of the actin cytoskeleton, and the control of vesicle fusion with the tip plasma membrane [12,52,140-143]. Lee et al. described how the activation of two antagonistic downstream pathways via the ROP-interactive CRIB-containing (RIC) proteins RIC3 and RIC4 manipulate F-actin polymerization: RIC4-mediated stabilisation of F-actin cables promotes vesicle transfer towards the tip [141]. However, RIC4-induced changes of actin structure impaired vesicle fusion at the pollen tip, which could be balanced by RIC3- and $\mathrm{Ca}^{2+}$-mediated F-actin disassembly. Thus, the authors suggested that Rop-GTPase activity triggers actin polymerisation for vesicle transport to the tip via the RIC4 pathway and actin depolymerisation at the tip for vesicle fusion via the RIC3 pathway. Together, these two pathways enable the transport and secretion of cell wall material at the tip [141]. Rop-controlled cell wall deposition relying on the manipulation of F-actin structure has also been observed in other context, e.g., the shaping of xylem vessels [144].

Studies in Arabidopsis characterised AtRop1 (also named Rac11 and Arac11) as a regulator of polarised pollen tube growth whose geranylgeranyl-mediated but spatially confined localisation to the tip is required for cell polarisation [145]. A second Arabidopsis enzyme, AtRop5 (also named Rac2, Rac6, and Arac6), seems to act similarly, and induces severe depolarisation phenotypes upon transient expression in tobacco [54]. Due to its close phylogenetic relationship, AtRop3 might have a similar function in pollen tubes [146]. In tobacco, NtRac5 has been described to regulate pollen tube growth in interaction with NtRhoGAP1 and NtRhoGDI2 $[147,148]$. AtRop1 was also proposed to be a mediator for changes in growth direction in response to pollen tube guidance cues. In a model that describes pollen tube tip growth as a result of the exocytosis-mediated polarisation of Rop1 and the secretory cell wall extension, guidance cues were predicted to shift the localisation of Rop1 activity and thus change growth directionality [12]. In this model, Rop1 activity is proposedly modulated by the activities of RopGEFs and the RhoGAP ROP1 ENHANCER 1. RopGEFs were then proposed as integration points for guidance cues, as an increased activation of Rop1 in response to a guidance cue would cause the shift in Rop1 activity and re-direction of secretion [12]. Consequently, RopGEFs, RhoGAPs, and RhoGDIs are important modulators of pollen tube growth due to their regulation of Rop/Rac GTPases [124,136,148-150]. Thus, male transmission defects were observed when RhoGDI function was missing in Arabidopsis [149]. Additional layers of modulation are characterised, e.g., phosphorylation of RopGEFs by cytoplasmic or receptor-like kinases, which was also described as a link between external signals and change of pollen tube growth directionality $[143,151,152]$. Guidance cues by the female gametophyte are required for precise pollen tube growth towards the micropyle [153]. Among the guidance cues described in Arabidopsis are the cysteine-rich AtLURE1-peptides, which are secreted from the synergid cells [154]. Reception of the AtLURE1 signals at the pollen tube relies on pollen-specific receptor-like kinases (PRKs) [143]. Specifically, AtPRK6 was determined as one receptor of AtLURE1 peptides as semi-in vivo grown pollen tubes of prk6 mutants did not react to recombinant AtLURE1.2. AtPRK6 displayed plasma membrane localisation at the pollen tube tip, and interestingly, an asymmetric accumulation of AtPRK6 towards externally applied AtLURE1 was observed, preceding the change of pollen tube growth direction. Signal transduction of AtPRK6 requires its interaction with pollen RopGEFs via a cytosolic domain: complementation 
of the AtLURE1-insensitivity in prk6 was not achieved when PRK6's cytosolic interaction domain to RopGEFs was missing [143]. Other receptor-like kinases present in Arabidopsis pollen tubes were also shown to react to AtLURE1 peptides [155]. The ectodomains of recombinant MALE DISCOVERER1 (AtMDIS1) and MDIS1-INTERACTING RECEPTOR-LIKE KINASE (AtMIK) 1/2 bind to AtLURE1.2. AtMDIS1 can directly interact with both AtMIK proteins and this interaction is enhanced by AtLURE1.2. However, unlike for AtPRK6, no connection to RopGEFs has been described, with signal transduction likely relying on transphosphorylation in the AtMDIS1-AtMIK complex [155]. It thus remains to be uncovered to which extent RhoGTPase activity is involved in pollen tube guidance and which role is played by other signalling modules.

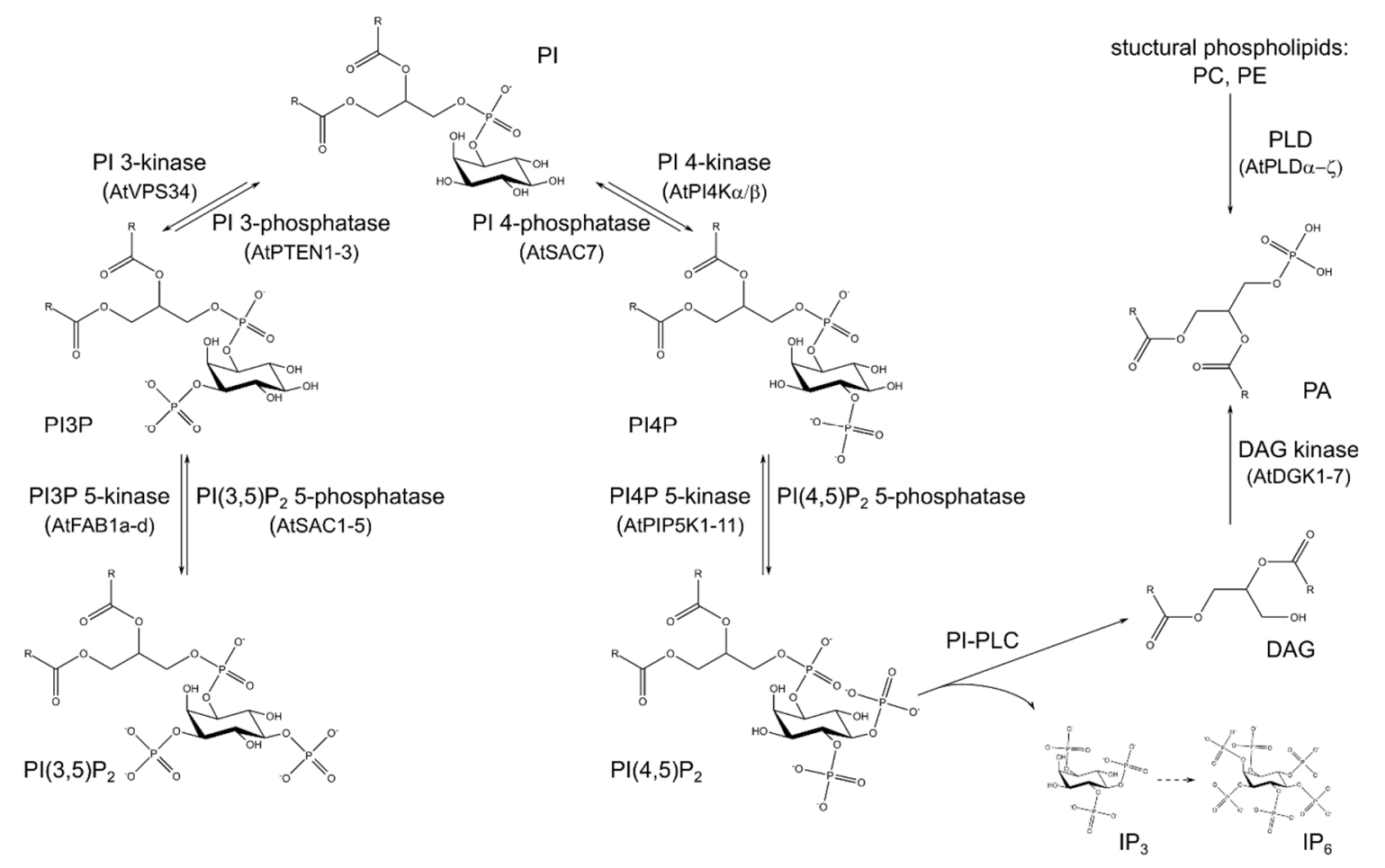

Figure 3. Signalling lipids are interconverted by a variety of enzymes. Phosphoinositides are phosphoglycerolipids carrying an inositol headgroup. Phosphorylation of different hydroxyl groups of the inositol in phosphatidylinositol (PI) gives rise to different monoand diphosphorylated phosphoinositides. Phospholipase C-activity cleaves the bond to the sn3-hydroxyl group of the glycerol backbone, yielding diacylglycerol (DAG) in the process, which can be phosphorylated to phosphatidic acid (PA). Used abbreviations: DAG-diacylglycerol, $\mathrm{IP}_{3}$-inositol 1,4,5-trisphosphate, $\mathrm{IP}_{6}$-inositolhexakisphosphate, PA-phosphatidic acid, PI-phosphatidylinositol, PI3P-phosphatidylinositol 3-phosphate, PI4P-phosphatidylinositol 4-phosphate, $\mathrm{PI}(3,5) \mathrm{P}_{2}$ - phosphatidylinositol 3,5-bisphosphate, $\mathrm{PI}(4,5) \mathrm{P}_{2}$ - phosphatidylinositol 4,5-bisphosphate, PI-PLC—phosphoinositide phospholipase C, PLD—phospholipase D.

Lipid signals act together with the mentioned regulatory proteins in the regulation of Rop GTPases [53,54]. Phosphatidylinositol 4,5-bisphosphate $\left(\mathrm{PI}(4,5) \mathrm{P}_{2}\right)$ acts upstream of Rop GTPase signalling by promoting plasma membrane localisation of GTP-Rop, which is part of a complex feedback loop to maintain the tip localisation of active Rop $[53,136]$. Due to the diverse membrane trafficking processes, the active enzyme constantly shifts to the flanks of the pollen tube tip. There, it has to be inactivated by laterally localised RhoGAP proteins [135]. RhoGDIs remove the inactive Rop GTPase from the subapical membrane and the RhoGDI/Rop-heterodimer is then transported in the cytoplasm back to the tip [147]. Tip-localised PI $(4,5) \mathrm{P}_{2}$ shifts the Rop GTPase equilibrium between cytoplasm and membrane towards a membranous localisation, and RopGEFs complete 
the cycling of the enzyme by exchanging GDP against GTP, activating Rop GTPase $[53,136,156]$. However, $\mathrm{PI}(4,5) \mathrm{P}_{2}$ was also described to act downstream of Rop GTPases. Tip-localised active AtRop5 interacts with a phosphatidylinositol 4-phosphate 5-kinase (PI4P5K), affecting the production of $\mathrm{PI}(4,5) \mathrm{P}_{2}$, which controls subsequent downstream pathways targeting the actin cytoskeleton and vesicle fusion [54].

\section{Phosphoinositides and Derived Lipids form a Signalling Network}

As becomes evident from the dependency of GTPase signalling on downstream signals like $\mathrm{PI}(4,5) \mathrm{P}_{2}$, the phosphoinositide signalling network (Figure 3), derived phospholipids, and the respective enzymes are crucial for normal pollen development and tube growth. The phosphatidylinositol headgroup of phosphoinositides protrudes from the plasma membrane, thus providing an anchor point for proteins with respective phosphoinositide-binding domains [7,157]. These binding domains can also be used for visualising the different lipids, as specific domains bind to the differently phosphorylated subspecies of phosphoinositides [158].

A

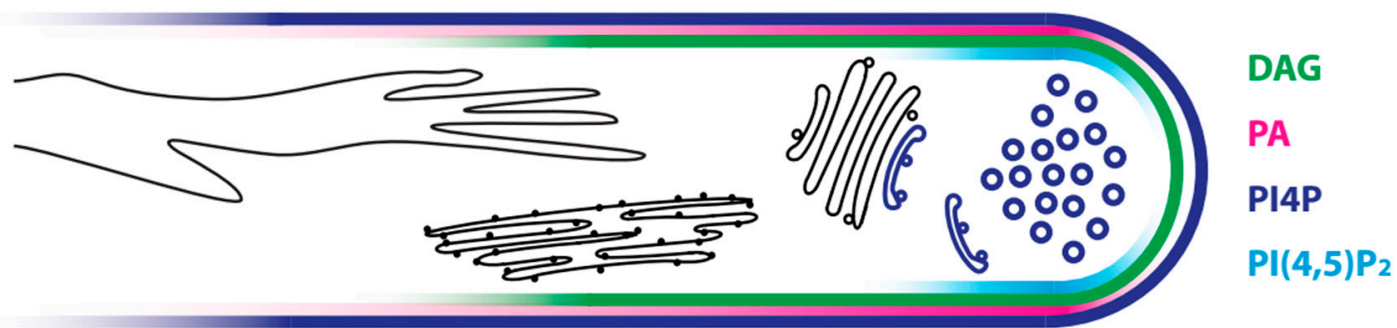

B

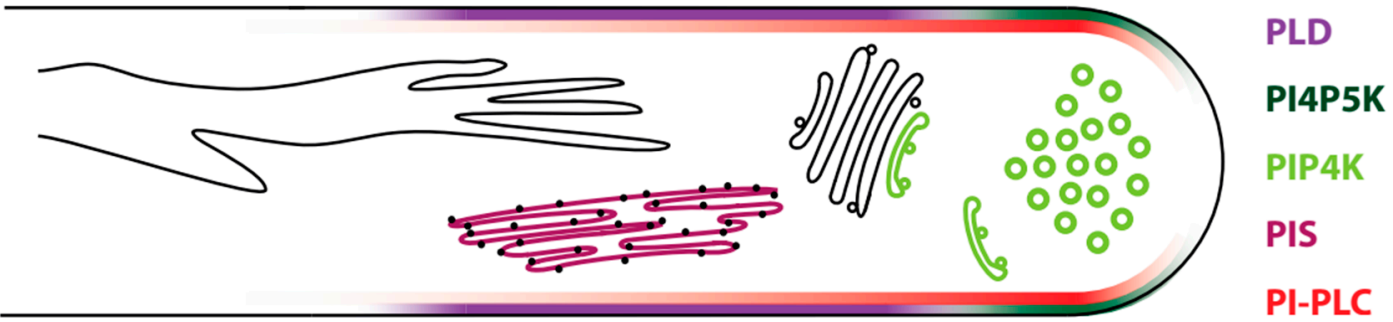

Figure 4. Several signalling lipids and the enzymes involved in their synthesis and degradation are localized at the apical plasma membrane. Several phosphoinositides and derived lipids are involved in pollen tube growth regulation. Their specific localisations in the plasma membrane are positional markers in secretory and endocytic processes and can be detected with the help of fluorescent lipid sensors (A). Enzymes acting on lipids of the phosphoinositide network show overlapping localisation to their products $(\mathbf{B})$.

\section{All Phosphoinositides Derive from Phosphatidylinositol}

All phosphoinositides derive from phosphatidylinositol (PI) as a biochemical precursor, which is synthesised in the membrane of the ER by phosphatidylinositol synthases (PISs) from the precursors CDP-diacylglycerol (CDP-DAG) and D-myo-inositol (Figure 3) [159,160]. Two PIS enzymes, AtPIS1 and AtPIS2, are described in Arabidopsis [159,160]. Interestingly, the metabolic fate of PI derived from AtPIS1 or AtPIS2 seems to differ. In Arabidopsis plants overexpressing AtPIS2, higher levels of phosphoinositides were detected in contrast to overexpression of AtPIS1 that caused an increase of 
structural phospholipids [160]. Transient overexpression of AtPIS1 or AtPIS2 in tobacco pollen tubes led to wavy growth phenotypes [161]. In line with the proposed different metabolic fates of PI produced by AtPIS1 or AtPIS2, expression of AtPIS2 led to a higher amount of affected pollen tubes. Similarly, co-expression effects of AtPIS2 with other genes encoding for enzymes of the phosphoinositide network were far more pronounced than for AtPIS1 [161].

The inositol of PI can carry phosphate groups in different positions, the D3-, D4-, or D5-position of the polyalcohol, giving rise to a number of different phosphoinositides. In plants, phosphatidylinositol 3-phosphate (PI3P), phosphatidylinositol 3,5-bisphosphate (PI $\left.(3,5) \mathrm{P}_{2}\right)$, phosphatidylinositol 4-phosphate (PI4P), and phosphatidylinositol 4,5-bisphosphate ( $\left.\mathrm{PI}(4,5) \mathrm{P}_{2}\right)$ have been characterised in different cellular functions. Of those, PI4P and PI $(4,5) \mathrm{P}_{2}$ are especially important in secretory processes and pollen tube growth $[7,162,163]$, as will be outlined in the next sections.

\section{PI4P Has Regulatory Roles in the Trans-Golgi Network}

Phosphatidylinositol 4-phosphate (PI4P) is the major monophosphorylated phosphoinositide $[164,165]$. Localisation studies in Arabidopsis demonstrated the presence of PI4P in the plasma membrane, recycling endosomes, early endosomes, the trans-Golgi network, and the Golgi complex [166]. Estimating from fluorescence intensity and affinity of the used lipid sensors, PI4P abundance seems to follow a gradient, with the highest PI4P amounts in the plasma membrane and lowest amounts in the Golgi complex [166]. In tip-growing root hairs, PI4P concentrations were highest in the plasma membrane following a tip-focused gradient $[167,168]$. A similar membrane localisation was observed in growing tobacco pollen tubes overexpressing a fluorescent PI4P-reporter [161] (Figure 4A).

Conversion of PI to PI4P is catalysed by phosphatidylinositol 4-kinases (PI4Ks). Among these, PI4K $\beta 1$ and PI4K $\beta 2$ are especially important for tip growth. In the Arabidopsis double mutant pi4k $\beta 1$ pi4k $\beta 2$, pollen tubes exhibit a wavy growth pattern and are shorter in length; furthermore, root hairs are also shorter and display aberrant growth morphologies. PI4K $\beta 1$ overexpression in tobacco pollen tubes stimulates pectin secretion [161]. For AtPI4K $\beta 1$, physical protein interaction with AtRab4Ab and AtRab4Ad was demonstrated and electron tomography imaging of Arabidopsis root cells showed that both AtRab4Ab and AtPI4K $\beta 1$ localise to the trans-Golgi network (TGN) $[132,169,170]$. Electron tomography images of root cells further indicated that PI4K $\beta 1$ and PI $4 \mathrm{~K} \beta 2$ might be vital for size determination of secretory vesicles at the TGN [169]. However, as the TGN integrates exocytic and endocytic vesicles, it cannot be determined if defects of PI4K $\beta$ impair exocytic or endocytic processes. In accordance with the described TGN-localisation, transient overexpression of AtPI4K $\beta 1$ in tobacco pollen tubes causes alterations of the TGN morphology. In addition, in the Arabidopsis mutant lot, which displays defects in TGN formation in pollen grain and pollen tubes, normal PI4P membrane localisation is abolished and lot plants are male-sterile [161,171]. Further studies showed additional signalling functions of PI4P and AtPI4Ks in vesicle trafficking and TGN organisation during cytokinesis and lateral root formation [172,173]. Although its synthesis is particularly linked to the TGN, PI4P strongly localises to the plasma membrane at the pollen tube tip. This discrepancy raises the question of how PI4P reaches the plasma membrane. One way could be via secretion of PI4P-loaded vesicles derived from the TGN. It is however also possible that PI4P is directly synthesized at the plasma membrane. Enzymes that might be responsible are PI kinase isoforms of the $\alpha$ subfamily that are predicted, for example, in Arabidopsis based on sequence homology [174]. Interestingly, in yeast, two types of PI4-kinases exist, one of which localizes to the plasma membrane $[175,176]$.

At the plasma membrane, PI4P could have a function in its own right, but can also act as a substrate for phosphatidylinositol 4-phosphate 5-kinases (PI4P5Ks) that are localised in the same plasma membrane sub-domain $[7,161]$.

\section{PI4P 5-Kinases Catalyse the Formation of PI(4,5) $\mathrm{P}_{2}$ at the Pollen Tube Tip}

PI4P5Ks catalyse the phosphorylation of PI4P to PI $(4,5) \mathrm{P}_{2}$. Arabidopsis PI4P5Ks come in two types: AtPI4P5K10 and AtPI4P5K11 belong to type A, while AtPI4P5K1 and AtPI4P5K9 belong to type B [174]. 
Both types contain a C-terminal catalytic and a dimerisation domain, however, type B AtPI4P5Ks possess an additional N-terminal Membrane Occupation and Recognition Nexus (MORN)-domain unique to plants, which is involved in regulation of enzyme activity $[174,177]$ and a linker region necessary for correct subcellular localisation [178].

According to transcriptomic studies, several Arabidopsis PI4P5Ks are expressed to varying degrees in the different stages of pollen development and during pollen tube growth $[179,180]$. For AtPI4P5K4, AtPI4P5K5, AtPI4P5K10, and AtPI4P5K11, expression in pollen and pollen tubes of Arabidopsis was also verified histochemically, using promoter- $\beta$-glucuronidase-fusion $[53,181]$. Furthermore, proteomic analyses detected AtPI4P5K4, AtPI4P5K5, and AtPI4P5K6 in mature pollen grains [182]. Transient expression of the respective gene in tobacco pollen tubes revealed a plasma membrane localisation of the PI4P5Ks at the subapical flanks during pollen tube growth (Figure 4B). After cessation of growth, PI4P5K localisation expanded to the extreme apex $[53,181,183,184]$. In parallel, PI $(4,5) \mathrm{P}_{2}$ localisation has been studied using fluorescent lipid sensors similar to the previously described phosphoinositides. In accordance with the plasma membrane localisation of its biosynthetic enzymes, $\mathrm{PI}(4,5) \mathrm{P}_{2}$ is detected almost exclusively at the plasma membrane of pollen tubes but also other cells, e.g., in the root cortex $[53,54,166,181]$. Furthermore, plasma membrane localisation in growing pollen tube membranes is not uniform, instead, $\mathrm{PI}(4,5) \mathrm{P}_{2}$ is present in a distinct subapical domain that excludes the very tip (Figure $4 \mathrm{~A}$ ). Apical localisation of $\mathrm{PI}(4,5) \mathrm{P}_{2}$ can only be found in pollen tubes that ceded to grow $[53,181,185]$.

Considering the tip-localisation of both PI4P5Ks and PI $(4,5) \mathrm{P}_{2}$, it is not surprising that strong tip growth phenotypes are observed for several AtPI4P5K enzymes. Overexpression of type A PI4P5Ks, AtPI4P5K10 and AtPI4P5K11, induces severe tip swelling and disturbance of the actin structure in tobacco pollen tubes, the overproduced $\mathrm{PI}(4,5) \mathrm{P}_{2}$ inhibits RhoGDI and thus leads to activation and depolarisation of NtRac5 [53]. For AtPI4P5K4, AtPI4P5K5, and AtPI4P5K6, overexpression phenotypes with excessive pectin accumulation are observed. The affected pollen tubes are often branched or stunted in growth, with the protoplast "trapped" behind the accumulated pectin at the tip $[181,183,184]$. Enzyme activity of PI4P5K6s from Arabidopsis and tobacco is further regulated by mitogen-activated protein (MAP) kinase (MPK)-mediated phosphorylation. MPK activity seems to diminish PI $(4,5) \mathrm{P}_{2}$-production, and when MPK was overexpressed with PI4P5Ks in tobacco pollen tubes, it could reduce the aberrant pollen tube growth phenotypes [186]. The PI4P5K-produced $\mathrm{PI}(4,5) \mathrm{P}_{2}$-signal is processed, i.e., via $\mathrm{PI}(4,5) \mathrm{P}_{2}$-interacting proteins, regulating endo- and exocytosis. The Arabidopsis clathrin assembly protein EPSIN-LIKE CLATHRIN ADAPTOR PROTEIN 2 (ECA2/ PICALM5a) interacts with $\mathrm{PI}(4,5) \mathrm{P}_{2}$ in vitro and pollen tubes of the eca2 T-DNA insertion Arabidopsis line grow shorter [187].

PI4P 5-kinases also play a role in polar tip growth and secretory processes of non-plant species [188-190]. In the nervous system, for example, PI4P is required for the normal function of several ion channels including calcium channels important for secretion [191]. However numerous other interaction partners are known, such as SNARE proteins and the proteins CAPS and Munc13 that prime vesicles for exocytosis [192]. It will be interesting to find out how conserved the role of $\operatorname{PI}(4,5) \mathrm{P}_{2}$ in secretion is across Eukaryotes. One complex that has already been shown to bind $\mathrm{PI}(4,5) \mathrm{P}_{2}$ across kingdoms [192-194] is the exocyst complex, that is crucial for secretory processes.

\section{PI(4,5) $\mathrm{P}_{2}$ Interacts with Components of the Exocyst Complex}

Targeting of secretory vesicles to the correct destination is determined by tethering complexes that physically connect vesicles to the target membrane. Among them, the exocyst complex is especially important for polarised exocytosis by tethering post-Golgi vesicles to the plasma membrane. It localises to sites of maximal exocytosis in a variety of model organisms, relying on interactions with both phospholipids and small monomeric G-proteins [195-197]. The complex was originally discovered in yeast but later found to be conserved in all eukaryotes, including plants [198-200]. The exocyst complex consists of eight subunits, termed SEC3, SEC5, SEC6, SEC8, SEC10, SEC15, EXO70, and EXO84. 
SEC5 is the core subunit and connects many other subunits with each other, SEC15 binds to vesicles, SEC6 interacts with SNARE proteins, and both SEC3 and EXO70 bind to PI $(4,5) \mathrm{P}_{2}$ on the target membrane [137,195,197,199,201-203]. However, unlike yeast, which has only one homologue of each subunit, Arabidopsis possesses two homologues of SEC3, SEC5, and SEC15 each, three homologues of EXO84 and, strikingly, 23 homologues of EXO70 in its genome [198,204].

First connections between the exocyst complex and $\mathrm{PI}(4,5) \mathrm{P}_{2}$ signalling were observed in yeast. There, the SEC3 homologue Sec3p contains a pleckstrin homology (PH) domain in its N-terminal region, which interacts with $\mathrm{PI}(4,5) \mathrm{P}_{2}$, mediating membrane binding $[196,197,205]$. The G-protein Rho1p can interact with the PH domain, presumably only if it is already bound to $\mathrm{PI}(4,5) \mathrm{P}_{2}$ [203]. Yeast Exo70p directly interacts with $\mathrm{PI}(4,5) \mathrm{P}_{2}$ through a polybasic region in its C-terminal domain and membrane binding of Exo70p was predicted to induce the local clustering of $\mathrm{PI}(4,5) \mathrm{P}_{2}$, potentially inducing formation of exocytic hotspots [203]. Mutation of the residues responsible for $\mathrm{PI}(4,5) \mathrm{P}_{2}$-binding leads to loss of Exo70p from the membrane, but not to secretion defects, while a combination of Exo70p and Sec3p mutations that leaves both proteins unable to bind lipids, was shown to be lethal in yeast [195,197].

Pollen tubes of Arabidopsis sec $3 a, \sec 5, \sec 6, \sec 8, \sec 15 a$, and exo70C2 mutants showed male-specific transmission defects as germination and pollen tube growth were disrupted [137,199,206,207]. For the two Arabidopsis SEC3 proteins, some homology to yeast Sec3p could be observed: the N-terminal $\mathrm{PI}(4,5) \mathrm{P}_{2}$-binding $\mathrm{PH}$ domain is conserved, however the Rho-interaction motif is not $[137,138]$. The PH domain of AtSEC3A is necessary and sufficient for membrane targeting during heterologous expression in tobacco pollen tubes but dispensable during homologous expression in Arabidopsis pollen tubes [137]. Similarly, $\mathrm{PI}(4,5) \mathrm{P}_{2}$ is not required for the localisation of AtSEC3A to the germination site in Arabidopsis pollen [208]. Both studies indicate that AtSEC3A can localise to the membrane independently of $\mathrm{PI}(4,5) \mathrm{P}_{2}$, possibly relying on other exocyst components or ROP G-proteins. Indeed, the Arabidopsis adapter protein ROP Interactive Partner 1 (ICR1) was found to compensate for the missing Rho-interaction motif of AtSEC3A by connecting it to the G-protein AtROP10 [138]. Whether similar adapter proteins play a role in pollen tube growth is not yet known.

Analysis of possible functional homology of the second yeast exocyst protein with $\mathrm{PI}(4,5) \mathrm{P}_{2}$-binding ability, Exo70p, is impeded by the massive expansion of EXO70 in plants. The reason for this massive expansion is so far unclear, although different explanations have been proposed, e.g., tissue-specific expression, differences according to target sites, or specialised roles in cellular processes like autophagy, cytokinesis, or pathogen infection [209-213]. The different EXO70 isoforms might also be capable of binding different lipids [209]. Indeed, in mature trichomes, AtEXO70H4 is selectively targeted to the PA/PS-rich apical membrane domain, whereas AtEXO70A1 is selectively targeted to the PI $(4,5) \mathrm{P}_{2}$-rich basal membrane domain [214]. In tobacco pollen tubes, NtEXO70A1a and NtEXO70B1 each localise to distinct parts of the plasma membrane, which both partially co-localise with PA and PI(4,5) $\mathrm{P}_{2}$ [215].

Independent of lipid binding capabilities, different EXO70 family members also might have different functions in pollen tube growth. While there are discrepancies in the described gene expression, most reports agree on the expression of AtEXO70A2, AtEXO70C1, AtEXO70C2, AtEXO70H3, and AtEXO70H5 in pollen tubes [204,207,215,216]. In most tissues of Arabidopsis, the prevalent EXO70 isoform that mediates polar exocytosis is AtEXO70A1. Although germination of exo70A1 mutant pollen is impaired, pollen tubes appear to grow normal, so its functions are probably complemented by AtEXO70A2 [204,207]. AtEXO70C1 and AtEXO70C2 likely serve functions distinct from the main exocyst complex, since they do not interact with the core exocyst subunits. However, AtEXO70C1 and AtEXO70C2 interact with AtROH1, a member of the DUF793 protein family, which acts as a negative regulator of exocytosis [207]. Roles of AtEXO70H3 and AtEXO70H5 in pollen tubes are so far undescribed, however, other plant $\mathrm{EXO} 70 \mathrm{H}$ proteins have been described to localise to the nucleus with possible functions independent of the core exocyst complex $[209,215,217]$. The tobacco NtEXO70B1 is expressed in pollen tubes and the encoded protein localises to the shank region of growing pollen 
tubes, partially co-localising with NtSEC3 and the site of endocytosis. This suggests that it might function within the exocyst complex in the coordination of endocytosis [215].

In agreement with its function in yeast exocytosis, the exocyst in plant pollen tubes is widely believed to guide exocytosis during tube growth. Different exocyst subunits localise to the described sites of exocytosis in the apex and/or the subapical zone, including SEC3, SEC6, SEC8, and EXO70A $[137,199,215]$. Additionally, slight shifts in the localisation of AtSEC3a and AtSEC8 were shown to precede changes in the direction of pollen tube growth [137]. Nonetheless, the molecular mechanism of the exocyst complex in pollen tube growth is still unclear. Early reports in budding yeast suggested that the lipid binding Sec3p and Exo70p might bind to the membrane, marking hotspots of exocytosis, while the other exocyst subunits bind to post-Golgi vesicles. Formation of the complete exocyst complex would then serve to tether vesicles to their correct target membrane [195,218]. In Arabidopsis root epidermal cells, however, it was reported that none of the exocyst subunits depend on vesicular traffic to localise to the membrane, indicating that the exocyst complex could pre-form on the target membrane and only then bind to vesicles [219]. On the other hand, AtSEC3a was shown to decorate vesicles in the inverted cone region of pollen tubes [137].

Taken together, molecular mechanisms of the exocyst complex in pollen tube growth remain elusive. Additional research will be required to fully resolve the order and the mechanism of interaction between exocyst, vesicles, and $\mathrm{PI}(4,5) \mathrm{P}_{2}$ in the target membrane and the connections of this complex to the signalling networks important for pollen tube growth.

\section{Dephosphorylation Reactions on PI4P and PI $(4,5) \mathrm{P}_{2}$}

The strong phenotypes resulting from the overexpression of PI 4-kinases and PI4P 5-kinases illustrate that the levels of PI4P and $\mathrm{PI}(4,5) \mathrm{P}_{2}$ must be tightly controlled. Furthermore, it seems crucial that the subdomain of the plasma membrane decorated with phosphoinositides remains clearly confined requiring the degradation of phosphoinositides diffusing out of this area. Therefore, phosphoinositides need to be degraded either by cleaving off their headgroup or by dephosphorylation. A cleavage reaction degrades the phosphoinositide "for good", yielding a lipid and a polyphosphorylated inositol as reaction products. In contrast, a dephosphorylation reaction takes a phosphoinositide one step back in the phosphorylation cascade so that it can be quickly rephosphorylated. Due to this, the dephosphorylation reactions of PI4P and PI $(4,5) \mathrm{P}_{2}$ have potential for a fine-tuning of PI4P and $\mathrm{PI}(4,5) \mathrm{P}_{2}$ concentrations. However, data on respective enzyme function in pollen tubes is scarce. The phosphatase ROOT HAIR DEFECTIVE4 (RHD4/SAC7) acts on the D4-phosphate in PI4P and is required for physiological tip growth in root hairs [7,167]. The protein has been detected in mature pollen grains and transient co-expression in tobacco pollen tubes showed a partial overlap in localisation with AtRabA4d in the endosomal compartment $[132,182]$. AtSAC7 is part of clade II of the suppressor of actin (SAC) phosphatases together with AtSAC6 and AtSAC8 [220]. Hence, it seems likely that AtSAC6 and AtSAC8 are PI4P-phosphatases as well, especially since all three are able to complement the yeast sac1 null mutant in a similar manner, yet there are no reports on the enzymatic activity of AtSAC6 and AtSAC8 [221]. Expression of AtSAC6 has been reported to be pollen-exclusive, especially high during pollen maturation, and it was found in a mutant screen to be required for $\beta$-aminobutyric acid-induced sterility [221,222]. A SAC protein homologue in rice acting on PI4P and PI(4,5)P2 was linked to actin polymerisation and adjustment of cell elongation [223]. However, despite their described involvement in cell growth and tip growth in root hairs and their expression in pollen, no connection to pollen tubes has been described so far for the clade II SAC phosphatases.

The clade III protein of Arabidopsis SAC phosphatases, AtSAC9, has been proposed to act on $\mathrm{PI}(4,5) \mathrm{P}_{2}$ and inositol 1,4,5-trisphosphate and in roots of the respective mutant these two compounds accumulated [224]. The sac 9 mutant further showed a constitutively stressed phenotype, which was later connected to defects in cell wall structure and disorganised deposition of cell wall material [224,225]. Other phosphatases acting on the D5-phosphate in $\mathrm{PI}(4,5) \mathrm{P}_{2}$ have been found in the protein family of plant $5^{\prime}$ phosphatases (5PTases) [226]. Arabidopsis possesses 15 proteins of the 5PTase family, 
which can be divided into two different groups based on their protein structure. At5PTase1-11 form group I, while group II contains At5Ptase12-15 (At5PTase15, mainly labelled AtFRA3) [226,227]. Substrate specificity is mixed in those groups, as different members from both groups show in vitro substrate preferences towards soluble inositol polyphosphates or hydrophobic phosphoinositides including $\mathrm{PI}(4,5) \mathrm{P}_{2}$ [226]. From group I At5PTases, only At5PTase5 is consistently expressed during different stages of the pollen life cycle, the corresponding protein was not found in mature pollen though $[179,180,182]$. In addition, involvement of the respective protein, variously labelled BST1, DER4, or MRH3, in the actual tip growth processes of root hairs or pollen in Arabidopsis seems to be minor [228,229]. The group II At5PTases genes At5PTase12-14 are expressed during pollen development and tube growth according to transcriptomic data, and all three encoded proteins are detected in mature pollen $[179,180,182]$. These three proteins have been characterised enzymatically, which revealed in vitro substrate preference for $\mathrm{PI}(4,5) \mathrm{P}_{2}$ in case of At5PTase14 and inositol 1,4,5-trisphosphate in case of At5PTase12/13. However, their in vivo substrate is unclear [230]. Hence, their role in the phosphoinositide network and possible impact on pollen tube growth and regulation of cell wall secretion remains to be studied.

\section{Activity of Phospholipase C Is the Main Degradation Route of Phosphoinositides}

In addition to modifications of their headgroup, phospholipids can be metabolised by phospholipases like phospholipase C (PLC) and phospholipase D (PLD) [231-233]. Cleavage of phospholipids by phospholipases C (PLCs) yields diacylglycerol (DAG) and the phosphorylated headgroup as products $[232,233]$. PLCs acting on lipid substrates can be divided into non-specific phospholipases C (NPCs) and phosphoinositide-phospholipases C (PI-PLC). PI-PLCs specifically use phosphoinositides as a substrate, while NPCs act on structural phospholipids like phosphatidylcholine (PC) or phosphatidylethanolamine (PE) [234,235]. Influences of Arabidopsis NPCs on root growth and pollen development but not pollen tube growth have been described [236-238]. In addition, so far, no Arabidopsis PI-PLC mutant was reported to be impaired in pollen tube growth. However, studies in other model systems highlighted PI-PLC importance to counterbalance PI4P5K-activity [185,239,240]. Petunia PiPLC1 and tobacco NtPLC3 both localise to the plasma membrane in growing pollen tubes, in overlapping regions with their substrate $\mathrm{PI}(4,5) \mathrm{P}_{2}$, although the protein localisation tends to elongate further towards the shank $[185,239]$. A similar co-localisation was observed for NtPLC3 and the Arabidopsis PI4P5Ks AtPI4P5K2 and 11 after transient expression in tobacco pollen tubes [240]. For petunia PiPLC1, image time series indicated that the PLC localisation extends towards the extreme apex in phases of reduced growth and is less apical in phases of rapid growth [185]. Dominant negative expression of PLCs mutated in their active site or chemical inhibition of NtPLC3 caused a depolarisation of tip growth and swollen tube tips $[185,239,240]$. Additionally, $\mathrm{PI}(4,5) \mathrm{P}_{2}$ visualised by a lipid sensor was observed to spread further towards the shank upon PLC-inhibition [239]. The pollen tube tip phenotype of swollen tips in tobacco pollen tubes was observed upon overexpression of inactive NtPLC3 and AtPI4P5K2; however, AtPI4P5K2-induced tip swelling could be reversed by simultaneous overexpression of active NtPLC3 [240]. Taken together, PLCs seem to be important in pollen tube tip growth as the main antagonist of PI4P5Ks, regulating $\mathrm{PI}(4,5) \mathrm{P}_{2}$ abundance and location.

\section{Inositol(poly)phosphates Are Receptors' Cofactors}

On the one hand, PLC activity abolishes the PI $(4,5) \mathrm{P}_{2}$-signal, while on the other hand, it produces two new molecules, inositol 1,4,5-trisphosphate $\left(\mathrm{IP}_{3}\right)$ and DAG. Cleavage of $\mathrm{PI}(4,5) \mathrm{P}_{2}$ to the second messengers $\mathrm{IP}_{3}$ and DAG is a common signal pathway in animal cells: DAG subsequently activates protein kinase $\mathrm{C}(\mathrm{PKC})$ while an $\mathrm{IP}_{3}$-receptor triggers the release of $\mathrm{Ca}^{2+}$ from intracellular storage [241]. However, neither for PKC nor for a canonical $\mathrm{IP}_{3}$-receptor do homologues exist in the Arabidopsis genome, so PLC-dependent responses seem to be transmitted differently [242,243]. In case of $\mathrm{IP}_{3}$, it was proposed that it rather acts as a precursor for higher phosphorylated inositol phosphates (IPs) and inositol pyrophosphates (IPPs) species like $\mathrm{IP}_{5}, \mathrm{IP}_{6}, \mathrm{IP}_{7}$, or $\mathrm{IP}_{8}[242,244,245]$. A signalling role for 
IPs was, for example, shown in the hormone signalling pathways of auxin and jasmonates, as the TIR1and COI1-receptor need the cofactors $\mathrm{IP}_{6}$ and $\mathrm{IP}_{5}$, respectively [246-250]. Both methyl jasmonate [251] and the auxin indole acetic acid [252] have been shown to influence pollen tube growth, indicating that these hormones can be perceived by the pollen tube and regulate its growth. Interestingly, IPs are also required for targeted pollen tube growth in Arabidopsis according to studies on ipk $2 \alpha$ and ipk $2 \beta$ mutants [253]. The IPK2 enzymes catalyse the reactions from $\mathrm{IP}_{3}$ to $\mathrm{IP}_{5}$, successive phosphorylations of the D6- and D3-position of the inositol ring. Single mutants were phenotypically inconspicuous, however, a double mutant could not be obtained, likely due to a male transmission defect, which could be traced to impaired pollen germination and pollen tube guidance [253].

\section{Diacylgylcerol Kinases Have Distinct Functions in Growing Pollen Tubes}

In the animal field, DAG, the second product of PLC-activity, was established to act as a second messenger and to activate protein kinase $C[254,255]$. However, so far, no plant orthologues of these protein kinases have been identified [256]. Consequently, a role of DAG in plant cell signalling is under debate, especially since it can be easily phosphorylated by DAG kinases (DGKs) to form PA, which makes a dissection of DAG-specific and PA-specific reactions difficult $[257,258]$. So far, a DAG-specific role has only been proposed to act in the development of lateral root under mild salt stress [259]. Hence, the question whether DAG has a signalling role of its own is still unanswered. In pollen tubes, DAG localises to the apex and stretches through the subapical region towards the shank, overlapping with localisation of PI-PLCs, which seem to be primary responsible for its synthesis [239]. DAG localisation also overlaps with PA-localisation, as determined by a fluorescent lipid sensor. PA shows extended localisation in the pollen tube subapical flanks, however is not present at the tube apex [260]. While part of the PA originates from PLD enzyme activity, as discussed below, PA could also be produced from PI-PLC-derived DAG by a phosphorylation reaction (Figure 2). DGKs phosphorylate the free hydroxyl group at the sn3-position of the glycerol in DAG, yielding PA [261]. Inhibitor studies with the PLD-inhibitor 1-butanol and the DGK-inhibitor R59022 were carried out in tobacco pollen tubes as a first attempt to study the specific effect of DGK-produced PA [262]. Changes in vacuole morphology were thus traced to DGK activity, as vacuolar strands formed aggregates that extended into the tip region. In contrast, DGK-derived PA is apparently not involved in actin organisation during pollen tube growth [262]. Arabidopsis DGKs form a seven-membered protein family, of which AtDGK4 is exclusively expressed in pollen, and proteomic analyses detected AtDGK4 and AtDGK5 in mature pollen grains. Similarly, a tobacco DAG kinase homologous to AtDGK5 was detected during all stages of tobacco pollen development [182,262,263]. Studies on one Arabidopsis T-DNA line of AtDGK4 reported decreased pollen tube growth rates for $d g k 4$ pollen [264]. Pollen tubes of $d g k 4$ exhibited altered cell wall properties; furthermore, the authors reported impaired membrane recycling, and additional defects in the pollen tube reaction to NO have been reported [264,265]. However, another recent study did not report significant phenotypes in the single $d g k 4$ mutant, only for the double mutant $d g k 2 d g k 4$ [266]. The respective enzymes DGK2 and DGK4 are localised to the ER and are probably involved in phospholipid metabolism there [266]. DGK function and DGK-derived PA have come into the focus of pollen tube research just recently, so the distinct sensors, transmitters, and effectors of PI-PLC/DGK-derived PA are still unexplored.

\section{Phospholipase D-Produced Phosphatidic Acid Regulates Pollen Tube Growth}

Unlike PLCs, which give rise to DAG, PLDs cleave phospholipids between the phosphate group and the headgroup, yielding PA [231,233]. In Arabidopsis, twelve PLDs are described differing in domain structure, enzymatic properties, and substrate preferences [243,267,268]. It is interesting to note that no Arabidopsis PLD activity on phosphoinositides has been reported, implying that PLC-mediated hydrolysis is the major pathway to terminate phosphoinositide signalling $[243,268]$. The origin of PLD-produced PA in pollen tubes is thus likely distinct from the PA produced by the concerted activity of PI-PLC and DGK, with the PI-PLC/DGK-pathway acting on phosphoinositides rather than structural 
phospholipids $[235,269]$. Nevertheless, PLD-activity has been demonstrated to be crucial for pollen tube growth using the PLD-inhibitor 1-butanol [270]. Subcellular analysis of tobacco pollen tubes treated with 1-butanol showed impairment of endocytosis, cell wall secretion, and actin regulation during tube growth [262]. The necessity of PA for exocytic processes has also been reported in various human cell types [271-273]. Two effects on secretion are generally discussed, firstly, that it could serve as a landmark in the plasma membrane, labelling the sites of exocytosis and recruiting proteins required for secretory processes. In this context, the anionic charge of its headgroup might help PA to interact with the positively charged domain of interacting proteins [272,274]. In line with this hypothesis, components of the tobacco exocyst complex partially colocalise with PA sensors in tobacco pollen tubes [215]. Secondly, PA influences biophysical properties of the membrane: its minimal headgroup results in a conical shape of the lipid, which in turn induces negative membrane curvature [274]. Membrane curvature is especially influential in vesicle formation so the shape of PA could be required for the endocytic recycling of vesicles at the pollen tube tip.

Several Arabidopsis PLD genes are expressed in pollen, and AtPLD $\alpha 1$, AtPLD $\alpha 2$, AtPLD $\beta 1$, and AtPLD $\delta$ are detected in mature pollen [182,262]. Despite this, no pollen tube growth phenotypes for Arabidopsis pld mutants have been described so far. In contrast, several tobacco PLDs are linked to pollen tube tip growth. Different NtPLDs were found to be expressed in pollen and germinated pollen, labelled NtPLD $\alpha 2, \mathrm{NtPLD} \beta 1$, and NtPLD $\delta$, and anti-sense-mediated knockdown of NtPLD $\beta 1$ and $N t P L D \delta$ impaired pollen tube growth [275]. Furthermore, for NtPLD $\beta 1$, actin-binding capacity and regulation of PLD-activity by actin was demonstrated, leading to the conclusion that NtPLD $\beta 1$ is a key regulatory factor of actin organisation during pollen tube growth [275]. For NtPLD 8 , a connection to ROS signalling was observed, as knockdown of NtPLD $\delta$ in tobacco pollen tubes led to a higher sensitivity towards $\mathrm{H}_{2} \mathrm{O}_{2}$. Interestingly, ROS-production by NtNOX itself is in part regulated by PLD-produced PA [62]. Recently, bioinformatic analysis of tobacco PLD $\delta$ s classified five different

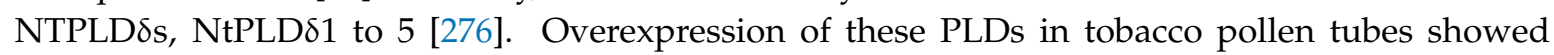
preferential cytosolic localisation for NtPLD $\delta 1$ and 2, plasma membrane localisation for NtPLD 44 and 5 , and an equilibrium between both compartments for NtPLD83. Tobacco pollen tubes overexpressing NtPLD83 showed the most severe phenotypes, including apical membrane invaginations. Due to the observed phenotypes, a role for NtPLD $\delta 3$ in membrane trafficking was proposed, highlighting the importance of lipid-mediated signalling for the maintenance of secretion in physiological tip growth [276].

\section{Outlook}

Many factors have been identified that are important for the polarisation of a pollen tube and its plasma membrane, including the channelling of secretory vesicles to the apical region by a highly specialised cytoskeleton and the regulation of exocytosis. This led to a model of a periodically oscillating system sustained and controlled by feedforward and feedback loops. In addition, external guidance cues and reacting receptors have been found. Now, the challenge emerges to understand how these external signals are integrated and transduced, so that cell wall properties are modulated that allow uneven tube extension and the pollen tube to "take a turn". Interesting questions can also be asked about the beginning and the end of pollen tube growth: How is the cell polarity originally established and how is the cell wall weakening orchestrated that ultimately leads to the bursting of the pollen tube and release of the sperm cells at the correct place? Finally, we must understand how this fragile system adapts to environmental stress to sustain pollen tube growth and why it fails in some species but not in others. This could highlight strategies for the future to prevent crop losses under weather and climate extremes.

Author Contributions: P.S., J.A., H.E.K. and T.I. contributed to the writing of the manuscript. P.S., H.E.K. and T.I. drafted and created the figures. All authors have read and agreed to the published version of the manuscript. 
Funding: This work was funded by the German Research Foundation (DFG, IRTG 2172 PRoTECT to T.I.), the Studienstiftung des deutschen Volkes (stipend to P.S.), and the International Max Planck Research School (scholarship to J.A.).

Acknowledgments: P.S. thanks Přemysl Pejchar and Martin Potocký for fruitful discussions.

Conflicts of Interest: The authors declare no conflict of interest.

\section{References}

1. Dehors, J.; Mareck, A.; Kiefer-Meyer, M.-C.; Menu-Bouaouiche, L.; Lehner, A.; Mollet, J.-C. Evolution of Cell Wall Polymers in Tip-Growing Land Plant Gametophytes: Composition, Distribution, Functional Aspects and Their Remodeling. Front. Plant. Sci. 2019, 10, 441. [CrossRef]

2. Johnson, M.A.; Harper, J.F.; Palanivelu, R. A Fruitful Journey: Pollen Tube Navigation from Germination to Fertilization. Ann. Rev. Plant. Biol. 2019, 70, 809-837. [CrossRef] [PubMed]

3. Amien, S.; Kliwer, I.; Márton, M.L.; Debener, T.; Geiger, D.; Becker, D.; Dresselhaus, T. Defensin-like ZmES4 mediates pollen tube burst in maize via opening of the potassium channel KZM1. PLoS Biol. 2010, 8, e1000388. [CrossRef] [PubMed]

4. Ge, Z.; Bergonci, T.; Zhao, Y.; Zou, Y.; Du, S.; Liu, M.-C.; Luo, X.; Ruan, H.; García-Valencia, L.E.; Zhong, S.; et al. Arabidopsis pollen tube integrity and sperm release are regulated by RALF-mediated signaling. Science 2017, 358, 1596-1600. [CrossRef] [PubMed]

5. Hamamura, Y.; Saito, C.; Awai, C.; Kurihara, D.; Miyawaki, A.; Nakagawa, T.; Kanaoka, M.M.; Sasaki, N.; Nakano, A.; Berger, F; et al. Live-cell imaging reveals the dynamics of two sperm cells during double fertilization in Arabidopsis thaliana. Curr. Biol. 2011, 21, 497-502. [CrossRef] [PubMed]

6. Grebnev, G.; Ntefidou, M.; Kost, B. Secretion and Endocytosis in Pollen Tubes: Models of Tip Growth in the Spot Light. Front. Plant. Sci. 2017, 8, 154. [CrossRef] [PubMed]

7. Heilmann, I.; Ischebeck, T. Male functions and malfunctions: The impact of phosphoinositides on pollen development and pollen tube growth. Plant. Reprod. 2016, 29, 3-20. [CrossRef]

8. Stephan, O.O.H. Actin fringes of polar cell growth. J. Exp. Bot. 2017, 68, 3303-3320. [CrossRef]

9. Williams, J.H. Novelties of the flowering plant pollen tube underlie diversification of a key life history stage. Proc. Natl. Acad. Sci. USA 2008, 105, 11259-11263. [CrossRef]

10. Bidhendi, A.J.; Geitmann, A. Finite Element Modeling of Shape Changes in Plant Cells. Plant. Physiol. 2018, 176, 41-56. [CrossRef]

11. Fayant, P.; Girlanda, O.; Chebli, Y.; Aubin, C.-E.; Villemure, I.; Geitmann, A. Finite Element Model of Polar Growth in Pollen Tubes. Plant. Cell 2010, 22, 2579-2593. [CrossRef]

12. Luo, N.; Yan, A.; Liu, G.; Guo, J.; Rong, D.; Kanaoka, M.M.; Xiao, Z.; Xu, G.; Higashiyama, T.; Cui, X.; et al. Exocytosis-coordinated mechanisms for tip growth underlie pollen tube growth guidance. Nat. Commun. 2017, 8, 1687. [CrossRef]

13. Zerzour, R.; Kroeger, J.; Geitmann, A. Polar growth in pollen tubes is associated with spatially confined dynamic changes in cell mechanical properties. Dev. Biol. 2009, 334, 437-446. [CrossRef]

14. Chebli, Y.; Kaneda, M.; Zerzour, R.; Geitmann, A. The Cell Wall of the Arabidopsis Pollen Tube-Spatial Distribution, Recycling, and Network Formation of Polysaccharides. Plant Physiol. 2012, 160, $1940-1955$. [CrossRef]

15. Parre, E.; Geitmann, A. Pectin and the role of the physical properties of the cell wall in pollen tube growth of Solanum chacoense. Planta 2005, 220, 582-592. [CrossRef]

16. Dardelle, F.; Lehner, A.; Ramdani, Y.; Bardor, M.; Lerouge, P.; Driouich, A.; Mollet, J.-C. Biochemical and immunocytological characterizations of Arabidopsis pollen tube cell wall. Plant. Physiol. 2010, 153, 1563-1576. [CrossRef]

17. Driouich, A.; Follet-Gueye, M.-L.; Bernard, S.; Kousar, S.; Chevalier, L.; Vicré-Gibouin, M.; Lerouxel, O. Golgi-mediated synthesis and secretion of matrix polysaccharides of the primary cell wall of higher plants. Front. Plant. Sci. 2012, 3, 79. [CrossRef]

18. Lenartowska, M.; Rodríguez-García, M.I.; Bednarska, E. Immunocytochemical localization of esterified and unesterified pectins in unpollinated and pollinated styles of Petunia hybrida Hort. Planta 2001, 213, 182-191. [CrossRef] [PubMed] 
19. Li, Y.Q.; Chen, F.; Linskens, H.F.; Cresti, M. Distribution of unesterified and esterified pectins in cell walls of pollen tubes of flowering plants. Sex. Plant. Reprod. 1994, 7. [CrossRef]

20. Mollet, J.-C.; Leroux, C.; Dardelle, F.; Lehner, A. Cell Wall Composition, Biosynthesis and Remodeling during Pollen Tube Growth. Plants 2013, 2, 107-147. [CrossRef] [PubMed]

21. Mravec, J.; Kračun, S.K.; Rydahl, M.G.; Westereng, B.; Pontiggia, D.; De Lorenzo, G.; Domozych, D.S.; Willats, W.G.T. An oligogalacturonide-derived molecular probe demonstrates the dynamics of calcium-mediated pectin complexation in cell walls of tip-growing structures. Plant. J. 2017, 91, 534-546. [CrossRef] [PubMed]

22. Bidhendi, A.J.; Chebli, Y.; Geitmann, A. Fluorescence visualization of cellulose and pectin in the primary plant cell wall. J. Microsc. 2020. [CrossRef] [PubMed]

23. Ferguson, C.; Teeri, T.T.; Siika-aho, M.; Read, S.M.; Bacic, A. Location of cellulose and callose in pollen tubes and grains of Nicotiana tabacum. Planta 1998, 206, 452-460. [CrossRef]

24. Bosch, M.; Cheung, A.Y.; Hepler, P.K. Pectin methylesterase, a regulator of pollen tube growth. Plant. Physiol. 2005, 138, 1334-1346. [CrossRef] [PubMed]

25. Jiang, L.; Yang, S.-L.; Xie, L.-F.; Puah, C.S.; Zhang, X.-Q.; Yang, W.-C.; Sundaresan, V.; Ye, D. VANGUARD1 Encodes a Pectin Methylesterase That Enhances Pollen Tube Growth in the Arabidopsis Style and Transmitting Tract. Plant. Cell 2005, 17, 584-596. [CrossRef] [PubMed]

26. Tang, C.; Zhu, X.; Qiao, X.; Gao, H.; Li, Q.; Wang, P.; Wu, J.; Zhang, S. Characterization of the pectin methyl-esterase gene family and its function in controlling pollen tube growth in pear (Pyrus bretschneideri). Genomics 2020, 112, 2467-2477. [CrossRef]

27. Tian, G.-W.; Chen, M.-H.; Zaltsman, A.; Citovsky, V. Pollen-specific pectin methylesterase involved in pollen tube growth. Dev. Biol. 2006, 294, 83-91. [CrossRef]

28. Pelloux, J.; Rusterucci, C.; Mellerowicz, E. New insights into pectin methylesterase structure and function. Trends Plant. Sci. 2007, 12, 267-277. [CrossRef]

29. Wang, M.; Yuan, D.; Gao, W.; Li, Y.; Tan, J.; Zhang, X. A comparative genome analysis of PME and PMEI families reveals the evolution of pectin metabolism in plant cell walls. PLoS ONE 2013, 8, e72082. [CrossRef]

30. Wormit, A.; Usadel, B. The Multifaceted Role of Pectin Methylesterase Inhibitors (PMEIs). Int. J. Mol. Sci. 2018, 19, 2878. [CrossRef]

31. Micheli, F. Pectin methylesterases: Cell wall enzymes with important roles in plant physiology. Trends Plant. Sci. 2001, 6, 414-419. [CrossRef]

32. Röckel, N.; Wolf, S.; Kost, B.; Rausch, T.; Greiner, S. Elaborate spatial patterning of cell-wall PME and PMEI at the pollen tube tip involves PMEI endocytosis, and reflects the distribution of esterified and de-esterified pectins. Plant. J. 2008, 53, 133-143. [CrossRef] [PubMed]

33. Derksen, J.; Rutten, T.; Lichtscheidl, I.K.; de Win, A.H.N.; Pierson, E.S.; Rongen, G. Quantitative analysis of the distribution of organelles in tobacco pollen tubes: Implications for exocytosis and endocytosis. Protoplasma 1995, 188, 267-276. [CrossRef]

34. Guan, Y.; Guo, J.; Li, H.; Yang, Z. Signaling in Pollen Tube Growth: Crosstalk, Feedback, and Missing Links. Mol. Plant. 2013, 6, 1053-1064. [CrossRef] [PubMed]

35. Mecchia, M.A.; Santos-Fernandez, G.; Duss, N.N.; Somoza, S.C.; Boisson-Dernier, A.; Gagliardini, V.; Martínez-Bernardini, A.; Fabrice, T.N.; Ringli, C.; Muschietti, J.P.; et al. RALF4/19 peptides interact with LRX proteins to control pollen tube growth in Arabidopsis. Science 2017, 358, 1600-1603. [CrossRef] [PubMed]

36. Derksen, J.; Rutten, T.; Van Amstel, T.; De Win, A.; Doris, F.; Steer, M. Regulation of pollen tube growth. Acta Bot. Neerl. 1995, 44, 93-119. [CrossRef]

37. Picton, J.M.; Steer, M.W. Membrane recycling and the control of secretory activity in pollen tubes. J. Cell. Sci. 1983, 63, 303-310.

38. Steer, M.W. Plasma Membrane Turnover in Plant Cells. J. Exp. Bot. 1988, 39, 987-996. [CrossRef]

39. Guo, J.; Yang, Z. Exocytosis and endocytosis: Coordinating and fine-tuning the polar tip growth domain in pollen tubes. J. Exp. Bot. 2020. [CrossRef]

40. Cole, R.A.; Fowler, J.E. Polarized growth: Maintaining focus on the tip. Curr. Opin. Plant. Biol. 2006, 9, 579-588. [CrossRef]

41. Cai, G.; Parrotta, L.; Cresti, M. Organelle trafficking, the cytoskeleton, and pollen tube growth: Organelle trafficking in pollen tubes. J. Integr. Plant. Biol. 2015, 57, 63-78. [CrossRef] [PubMed] 
42. Hepler, P.K.; Winship, L.J. The pollen tube clear zone: Clues to the mechanism of polarized growth: Differential organelle movement creates a clear zone. J. Integr. Plant. Biol. 2015, 57, 79-92. [CrossRef] [PubMed]

43. Hepler, P.K.; Vidali, L.; Cheung, A.Y. Polarized Cell Growth in Higher Plants. Ann. Rev. Cell Dev. Biol. 2001, 17, 159-187. [CrossRef]

44. Chebli, Y.; Kroeger, J.; Geitmann, A. Transport Logistics in Pollen Tubes. Mol. Plant. 2013, 6, 1037-1052. [CrossRef] [PubMed]

45. Adhikari, P.B.; Liu, X.; Wu, X.; Zhu, S.; Kasahara, R.D. Fertilization in flowering plants: An odyssey of sperm cell delivery. Plant. Mol. Biol. 2020. [CrossRef]

46. Ischebeck, T.; Seiler, S.; Heilmann, I. At the poles across kingdoms: Phosphoinositides and polar tip growth. Protoplasma 2010, 240, 13-31. [CrossRef]

47. Michard, E.; Simon, A.A.; Tavares, B.; Wudick, M.M.; Feijó, J.A. Signaling with Ions: The Keystone for Apical Cell Growth and Morphogenesis in Pollen Tubes. Plant. Physiol. 2017, 173, 91-111. [CrossRef]

48. Scheible, N.; McCubbin, A. Signaling in Pollen Tube Growth: Beyond the Tip of the Polarity Iceberg. Plants (Basel) 2019, 8, 156. [CrossRef]

49. Steinhorst, L.; Kudla, J. Calcium-A central regulator of pollen germination and tube growth. Biochim. Biophys. Acta (BBA) Mol. Cell Res. 2013, 1833, 1573-1581. [CrossRef]

50. Vogler, H.; Santos-Fernandez, G.; Mecchia, M.A.; Grossniklaus, U. To preserve or to destroy, that is the question: The role of the cell wall integrity pathway in pollen tube growth. Curr. Opin. Plant. Biol. 2019, 52, 131-139. [CrossRef]

51. Zhang, M.J.; Zhang, X.S.; Gao, X.-Q. ROS in the Male-Female Interactions During Pollination: Function and Regulation. Front. Plant. Sci. 2020, 11, 177. [CrossRef] [PubMed]

52. Gu, Y.; Fu, Y.; Dowd, P.; Li, S.; Vernoud, V.; Gilroy, S.; Yang, Z. A Rho family GTPase controls actin dynamics and tip growth via two counteracting downstream pathways in pollen tubes. J. Cell Biol. 2005, 169, 127-138. [CrossRef] [PubMed]

53. Ischebeck, T.; Stenzel, I.; Hempel, F.; Jin, X.; Mosblech, A.; Heilmann, I. Phosphatidylinositol-4,5-bisphosphate influences Nt-Rac5-mediated cell expansion in pollen tubes of Nicotiana tabacum: PtdIns(4,5)P2 and polar tip growth. Plant. J. 2011, 65, 453-468. [CrossRef] [PubMed]

54. Kost, B.; Lemichez, E.; Spielhofer, P.; Hong, Y.; Tolias, K.; Carpenter, C.; Chua, N.-H. Rac Homologues and Compartmentalized Phosphatidylinositol 4, 5-Bisphosphate Act in a Common Pathway to Regulate Polar Pollen Tube Growth. J. Cell Biol. 1999, 145, 317-330. [CrossRef] [PubMed]

55. Haduch-Sendecka, A.; Pietruszka, M.; Zajdel, P. Power spectrum, growth velocities and cross-correlations of longitudinal and transverse oscillations of individual Nicotiana tabacum pollen tube. Planta 2014, 240, 263-276. [CrossRef]

56. Hemelryck, M.V.; Bernal, R.; Ispolatov, Y.; Dumais, J. Lily Pollen Tubes Pulse According to a Simple Spatial Oscillator. Sci. Rep. 2018, 8, 12135. [CrossRef]

57. Hwang, J.-U.; Gu, Y.; Lee, Y.-J.; Yang, Z. Oscillatory ROP GTPase activation leads the oscillatory polarized growth of pollen tubes. Mol. Biol. Cell 2005, 16, 5385-5399. [CrossRef]

58. Qin, Y.; Dong, J. Focusing on the Focus: What Else beyond the Master Switches for Polar Cell Growth? Mol. Plant. 2015, 8, 582-594. [CrossRef]

59. Yan, A.; Xu, G.; Yang, Z.-B. Calcium participates in feedback regulation of the oscillating ROP1 Rho GTPase in pollen tubes. Proc. Natl. Acad. Sci. USA 2009, 106, 22002-22007. [CrossRef]

60. Duan, Q.; Kita, D.; Johnson, E.A.; Aggarwal, M.; Gates, L.; Wu, H.-M.; Cheung, A.Y. Reactive oxygen species mediate pollen tube rupture to release sperm for fertilization in Arabidopsis. Nat. Commun. 2014, 5, 3129. [CrossRef]

61. Potocký, M.; Jones, M.A.; Bezvoda, R.; Smirnoff, N.; Žárský, V. Reactive oxygen species produced by NADPH oxidase are involved in pollen tube growth. New Phytol. 2007, 174, 742-751. [CrossRef] [PubMed]

62. Potocký, M.; Pejchar, P.; Gutkowska, M.; Jiménez-Quesada, M.J.; Potocká, A.; de Dios Alché, J.; Kost, B.; Žárský, V. NADPH oxidase activity in pollen tubes is affected by calcium ions, signaling phospholipids and Rac/Rop GTPases. J. Plant. Physiol. 2012, 169, 1654-1663. [CrossRef]

63. Cárdenas, L.; McKenna, S.T.; Kunkel, J.G.; Hepler, P.K. NAD(P)H oscillates in pollen tubes and is correlated with tip growth. Plant. Physiol. 2006, 142, 1460-1468. [CrossRef] 
64. Gao, Y.-B.; Wang, C.-L.; Wu, J.-Y.; Zhou, H.-S.; Jiang, X.-T.; Wu, J.; Zhang, S.-L. Low temperature inhibits pollen tube growth by disruption of both tip-localized reactive oxygen species and endocytosis in Pyrus bretschneideri Rehd. Plant. Physiol. Biochem. 2014, 74, 255-262. [CrossRef] [PubMed]

65. Jimenez-Quesada, M.J.; Traverso, J.A.; Potocký, M.; Žárský, V.; Alché, J.D.D. Generation of Superoxide by OeRbohH, a NADPH Oxidase Activity During Olive (Olea europaea L.) Pollen Development and Germination. Front. Plant. Sci. 2019, 10, 1149. [CrossRef] [PubMed]

66. Liu, P.; Li, R.-L.; Zhang, L.; Wang, Q.-L.; Niehaus, K.; Baluska, F.; Samaj, J.; Lin, J.-X. Lipid microdomain polarization is required for NADPH oxidase-dependent ROS signaling in Picea meyeri pollen tube tip growth. Plant. J. 2009, 60, 303-313. [CrossRef]

67. Speranza, A.; Crinelli, R.; Scoccianti, V.; Geitmann, A. Reactive oxygen species are involved in pollen tube initiation in kiwifruit. Plant. Biol. (Stuttg) 2012, 14, 64-76. [CrossRef]

68. Kaya, H.; Nakajima, R.; Iwano, M.; Kanaoka, M.M.; Kimura, S.; Takeda, S.; Kawarazaki, T.; Senzaki, E.; Hamamura, Y.; Higashiyama, T.; et al. $\mathrm{Ca}^{2+}$-activated reactive oxygen species production by Arabidopsis $\mathrm{RbohH}$ and RbohJ is essential for proper pollen tube tip growth. Plant. Cell 2014, 26, 1069-1080. [CrossRef]

69. Lassig, R.; Gutermuth, T.; Bey, T.D.; Konrad, K.R.; Romeis, T. Pollen tube NAD(P)H oxidases act as a speed control to dampen growth rate oscillations during polarized cell growth. Plant. J. 2014, 78, 94-106. [CrossRef]

70. Boisson-Dernier, A.; Lituiev, D.S.; Nestorova, A.; Franck, C.M.; Thirugnanarajah, S.; Grossniklaus, U. ANXUR Receptor-Like Kinases Coordinate Cell Wall Integrity with Growth at the Pollen Tube Tip Via NADPH Oxidases. PLoS Biol. 2013, 11, e1001719. [CrossRef]

71. Feng, H.; Liu, C.; Fu, R.; Zhang, M.; Li, H.; Shen, L.; Wei, Q.; Sun, X.; Xu, L.; Ni, B.; et al. LORELEI-LIKE GPI-ANCHORED PROTEINS 2/3 Regulate Pollen Tube Growth as Chaperones and Coreceptors for ANXUR/BUPS Receptor Kinases in Arabidopsis. Mol. Plant. 2019, 12, 1612-1623. [CrossRef] [PubMed]

72. Zhu, L.; Chu, L.-C.; Liang, Y.; Zhang, X.-Q.; Chen, L.-Q.; Ye, D. The Arabidopsis CrRLK1L protein kinases BUPS1 and BUPS2 are required for normal growth of pollen tubes in the pistil. Plant. J. 2018, 95, 474-486. [CrossRef]

73. Ge, Z.; Cheung, A.Y.; Qu, L. Pollen tube integrity regulation in flowering plants: Insights from molecular assemblies on the pollen tube surface. New Phytol. 2019, 222, 687-693. [CrossRef] [PubMed]

74. Benkő, P.; Jee, S.; Kaszler, N.; Fehér, A.; Gémes, K. Polyamines treatment during pollen germination and pollen tube elongation in tobacco modulate reactive oxygen species and nitric oxide homeostasis. J. Plant. Physiol. 2020, 244, 153085. [CrossRef]

75. Wu, J.; Shang, Z.; Wu, J.; Jiang, X.; Moschou, P.N.; Sun, W.; Roubelakis-Angelakis, K.A.; Zhang, S. Spermidine oxidase-derived $\mathrm{H}_{2} \mathrm{O}_{2}$ regulates pollen plasma membrane hyperpolarization-activated $\mathrm{Ca}(2+)$-permeable channels and pollen tube growth. Plant. J. 2010, 63, 1042-1053. [CrossRef] [PubMed]

76. Do, T.H.T.; Choi, H.; Palmgren, M.; Martinoia, E.; Hwang, J.-U.; Lee, Y. Arabidopsis ABCG28 is required for the apical accumulation of reactive oxygen species in growing pollen tubes. Proc. Natl. Acad. Sci. USA 2019, 116, 12540-12549. [CrossRef]

77. Mangano, S.; Juárez, S.P.D.; Estevez, J.M. ROS Regulation of Polar Growth in Plant Cells. Plant. Physiol. 2016, 171, 1593-1605. [CrossRef]

78. Podolyan, A.; Maksimov, N.; Breygina, M. Redox-regulation of ion homeostasis in growing lily pollen tubes. J. Plant. Physiol. 2019, 243, 153050. [CrossRef]

79. Zhang, Y.; Zhu, H.; Zhang, Q.; Li, M.; Yan, M.; Wang, R.; Wang, L.; Welti, R.; Zhang, W.; Wang, X. Phospholipase D $\alpha 1$ and Phosphatidic Acid Regulate NADPH Oxidase Activity and Production of Reactive Oxygen Species in ABA-Mediated Stomatal Closure in Arabidopsis. Plant. Cell 2009, 21, 2357-2377. [CrossRef]

80. Wudick, M.M.; Feijó, J.A. At the intersection: Merging $\mathrm{Ca}^{2+}$ and ROS signaling pathways in pollen. Mol. Plant. 2014, 7, 1595-1597. [CrossRef]

81. Feijó, J.A.; Sainhas, J.; Hackett, G.R.; Kunkel, J.G.; Hepler, P.K. Growing pollen tubes possess a constitutive alkaline band in the clear zone and a growth-dependent acidic tip. J. Cell Biol. 1999, 144, 483-496. [CrossRef] [PubMed]

82. Certal, A.C.; Almeida, R.B.; Carvalho, L.M.; Wong, E.; Moreno, N.; Michard, E.; Carneiro, J.; Rodriguéz-Léon, J.; Wu, H.-M.; Cheung, A.Y; et al. Exclusion of a Proton ATPase from the Apical Membrane Is Associated with Cell Polarity and Tip Growth in Nicotiana tabacum Pollen Tubes. Plant. Cell 2008, 20, 614-634. [CrossRef] 
83. Michard, E.; Dias, P.; Feijó, J.A. Tobacco pollen tubes as cellular models for ion dynamics: Improved spatial and temporal resolution of extracellular flux and free cytosolic concentration of calcium and protons using pHluorin and YC3.1 CaMeleon. Sex. Plant. Reprod. 2008, 21, 169-181. [CrossRef]

84. Fricker, M.D.; White, N.S.; Obermeyer, G. pH gradients are not associated with tip growth in pollen tubes of Lilium longiflorum. J. Cell. Sci. 1997, 110 Pt 15, 1729-1740.

85. Lovy-Wheeler, A.; Kunkel, J.G.; Allwood, E.G.; Hussey, P.J.; Hepler, P.K. Oscillatory increases in alkalinity anticipate growth and may regulate actin dynamics in pollen tubes of lily. Plant. Cell 2006, 18, 2182-2193. [CrossRef] [PubMed]

86. Winship, L.J.; Rounds, C.; Hepler, P.K. Perturbation Analysis of Calcium, Alkalinity and Secretion during Growth of Lily Pollen Tubes. Plants (Basel) 2016, 6, 3. [CrossRef] [PubMed]

87. Domingos, P.; Dias, P.N.; Tavares, B.; Portes, M.T.; Wudick, M.M.; Konrad, K.R.; Gilliham, M.; Bicho, A.; Feijó, J.A. Molecular and electrophysiological characterization of anion transport in Arabidopsis thaliana pollen reveals regulatory roles for $\mathrm{pH}, \mathrm{Ca}^{2+}$ and GABA. New Phytol. 2019, 223, 1353-1371. [CrossRef]

88. Hoffmann, R.D.; Portes, M.T.; Olsen, L.I.; Damineli, D.S.C.; Hayashi, M.; Nunes, C.O.; Pedersen, J.T.; Lima, P.T.; Campos, C.; Feijó, J.A.; et al. Plasma membrane H+-ATPases sustain pollen tube growth and fertilization. Nat. Commun. 2020, 11, 2395. [CrossRef]

89. Brewbaker, J.L.; Kwack, B.H. THE ESSENTIAL ROLE OF CALCIUM ION IN POLLEN GERMINATION AND POLLEN TUBE GROWTH. Am. J. Bot. 1963, 50, 859-865. [CrossRef]

90. Denninger, P.; Bleckmann, A.; Lausser, A.; Vogler, F.; Ott, T.; Ehrhardt, D.W.; Frommer, W.B.; Sprunck, S.; Dresselhaus, T.; Grossmann, G. Male-female communication triggers calcium signatures during fertilization in Arabidopsis. Nat. Commun. 2014, 5, 4645. [CrossRef]

91. Hamamura, Y.; Nishimaki, M.; Takeuchi, H.; Geitmann, A.; Kurihara, D.; Higashiyama, T. Live imaging of calcium spikes during double fertilization in Arabidopsis. Nat. Commun. 2014, 5, 4722. [CrossRef] [PubMed]

92. Holdaway-Clarke, T.L.; Feijo, J.A.; Hackett, G.R.; Kunkel, J.G.; Hepler, P.K. Pollen Tube Growth and the Intracellular Cytosolic Calcium Gradient Oscillate in Phase while Extracellular Calcium Influx Is Delayed. Plant. Cell 1997, 9, 1999-2010. [CrossRef] [PubMed]

93. Pierson, E.S.; Miller, D.D.; Callaham, D.A.; van Aken, J.; Hackett, G.; Hepler, P.K. Tip-localized calcium entry fluctuates during pollen tube growth. Dev. Biol. 1996, 174, 160-173. [CrossRef] [PubMed]

94. Malho, R.; Trewavas, A.J. Localized Apical Increases of Cytosolic Free Calcium Control Pollen Tube Orientation. Plant. Cell 1996, 8, 1935-1949. [CrossRef]

95. Zheng, R.; Su, S.; Xiao, H.; Tian, H. Calcium: A Critical Factor in Pollen Germination and Tube Elongation. Int. J. Mol. Sci. 2019, 20, 420. [CrossRef]

96. Iwano, M.; Entani, T.; Shiba, H.; Kakita, M.; Nagai, T.; Mizuno, H.; Miyawaki, A.; Shoji, T.; Kubo, K.; Isogai, A.; et al. Fine-tuning of the cytoplasmic $\mathrm{Ca}^{2+}$ concentration is essential for pollen tube growth. Plant. Physiol. 2009, 150, 1322-1334. [CrossRef]

97. Obermeyer, G.; Weisenseel, M.H. Calcium channel blocker and calmodulin antagonists affect the gradient of free calcium ions in lily pollen tubes. Eur. J. Cell Biol. 1991, 56, 319-327. [PubMed]

98. Pierson, E.S.; Miller, D.D.; Callaham, D.A.; Shipley, A.M.; Rivers, B.A.; Cresti, M.; Hepler, P.K. Pollen tube growth is coupled to the extracellular calcium ion flux and the intracellular calcium gradient: Effect of BAPTA-type buffers and hypertonic media. Plant. Cell 1994, 6, 1815-1828. [CrossRef]

99. Dutta, R.; Robinson, K.R. Identification and characterization of stretch-activated ion channels in pollen protoplasts. Plant. Physiol. 2004, 135, 1398-1406. [CrossRef]

100. Frietsch, S.; Wang, Y.-F.; Sladek, C.; Poulsen, L.R.; Romanowsky, S.M.; Schroeder, J.I.; Harper, J.F. A cyclic nucleotide-gated channel is essential for polarized tip growth of pollen. Proc. Natl. Acad. Sci. USA 2007, 104, 14531-14536. [CrossRef]

101. Michard, E.; Lima, P.T.; Borges, F.; Silva, A.C.; Portes, M.T.; Carvalho, J.E.; Gilliham, M.; Liu, L.-H.; Obermeyer, G.; Feijó, J.A. Glutamate receptor-like genes form $\mathrm{Ca}^{2+}$ channels in pollen tubes and are regulated by pistil D-serine. Science 2011, 332, 434-437. [CrossRef]

102. Wudick, M.M.; Portes, M.T.; Michard, E.; Rosas-Santiago, P.; Lizzio, M.A.; Nunes, C.O.; Campos, C.; Santa Cruz Damineli, D.; Carvalho, J.C.; Lima, P.T.; et al. CORNICHON sorting and regulation of GLR channels underlie pollen tube $\mathrm{Ca}^{2+}$ homeostasis. Science 2018, 360, 533-536. [CrossRef] [PubMed] 
103. Lamport, D.T.A.; Tan, L.; Held, M.A.; Kieliszewski, M.J. Pollen tube growth and guidance: Occam's razor sharpened on a molecular arabinogalactan glycoprotein Rosetta Stone. New Phytol. 2018, 217, 491-500. [CrossRef] [PubMed]

104. Li, Y.; Guo, J.; Yang, Z.; Yang, D.-L. Plasma Membrane-Localized Calcium Pumps and Copines Coordinately Regulate Pollen Germination and Fertility in Arabidopsis. Int. J. Mol. Sci. 2018, 19, 1774. [CrossRef] [PubMed]

105. Schiøtt, M.; Romanowsky, S.M.; Baekgaard, L.; Jakobsen, M.K.; Palmgren, M.G.; Harper, J.F. A plant plasma membrane $\mathrm{Ca}^{2+}$ pump is required for normal pollen tube growth and fertilization. Proc. Natl. Acad. Sci. USA 2004, 101, 9502-9507. [CrossRef]

106. Ramakrishnan, S.; Bera, M.; Coleman, J.; Rothman, J.E.; Krishnakumar, S.S. Synergistic roles of Synaptotagmin-1 and complexin in calcium-regulated neuronal exocytosis. Elife 2020, 9. [CrossRef]

107. Zhou, Q.; Zhou, P.; Wang, A.L.; Wu, D.; Zhao, M.; Südhof, T.C.; Brunger, A.T. The primed SNARE-complexin-synaptotagmin complex for neuronal exocytosis. Nature 2017, 548, 420-425. [CrossRef] [PubMed]

108. Pozzi, D.; Corradini, I.; Matteoli, M. The Control of Neuronal Calcium Homeostasis by SNAP-25 and its Impact on Neurotransmitter Release. Neuroscience 2019, 420, 72-78. [CrossRef] [PubMed]

109. Harmon, A.C.; Gribskov, M.; Gubrium, E.; Harper, J.F. The CDPK superfamily of protein kinases: Research review. New Phytol. 2001, 151, 175-183. [CrossRef]

110. Li, J.; Li, Y.; Deng, Y.; Chen, P.; Feng, F.; Chen, W.; Zhou, X.; Wang, Y. A calcium-dependent protein kinase, ZmCPK32, specifically expressed in maize pollen to regulate pollen tube growth. PLoS ONE 2018, 13, e0195787. [CrossRef]

111. Myers, C.; Romanowsky, S.M.; Barron, Y.D.; Garg, S.; Azuse, C.L.; Curran, A.; Davis, R.M.; Hatton, J.; Harmon, A.C.; Harper, J.F. Calcium-dependent protein kinases regulate polarized tip growth in pollen tubes. Plant. J. 2009, 59, 528-539. [CrossRef] [PubMed]

112. Yoon, G.M.; Dowd, P.E.; Gilroy, S.; McCubbin, A.G. Calcium-dependent protein kinase isoforms in Petunia have distinct functions in pollen tube growth, including regulating polarity. Plant. Cell 2006, 18, 867-878. [CrossRef]

113. Gutermuth, T.; Lassig, R.; Portes, M.-T.; Maierhofer, T.; Romeis, T.; Borst, J.-W.; Hedrich, R.; Feijo, J.A.; Konrad, K.R. Pollen Tube Growth Regulation by Free Anions Depends on the Interaction between the Anion Channel SLAH3 and Calcium-Dependent Protein Kinases CPK2 and CPK20. Plant. Cell 2013, 25, 4525-4543. [CrossRef] [PubMed]

114. Zhao, L.-N.; Shen, L.-K.; Zhang, W.-Z.; Zhang, W.; Wang, Y.; Wu, W.-H. Ca ${ }^{2+}$-dependent protein kinase11 and 24 modulate the activity of the inward rectifying $\mathrm{K}+$ channels in Arabidopsis pollen tubes. Plant. Cell 2013, 25, 649-661. [CrossRef] [PubMed]

115. Gutermuth, T.; Herbell, S.; Lassig, R.; Brosché, M.; Romeis, T.; Feijó, J.A.; Hedrich, R.; Konrad, K.R. Tip-localized $\mathrm{Ca}^{2+}$-permeable channels control pollen tube growth via kinase-dependent $\mathrm{R}$ - and S-type anion channel regulation. New Phytol. 2018, 218, 1089-1105. [CrossRef] [PubMed]

116. Herbell, S.; Gutermuth, T.; Konrad, K.R. An interconnection between tip-focused $\mathrm{Ca}^{2+}$ and anion homeostasis controls pollen tube growth. Plant. Signal. Behav. 2018, 13, e1529521. [CrossRef] [PubMed]

117. Mähs, A.; Steinhorst, L.; Han, J.-P.; Shen, L.-K.; Wang, Y.; Kudla, J. The calcineurin B-like Ca ${ }^{2+}$ sensors CBL1 and CBL9 function in pollen germination and pollen tube growth in Arabidopsis. Mol. Plant. 2013, 6, 1149-1162. [CrossRef] [PubMed]

118. Steinhorst, L.; Mähs, A.; Ischebeck, T.; Zhang, C.; Zhang, X.; Arendt, S.; Schültke, S.; Heilmann, I.; Kudla, J. Vacuolar CBL-CIPK12 $\mathrm{Ca}^{2+}$-Sensor-Kinase Complexes Are Required for Polarized Pollen Tube Growth. Curr. Biol. 2015, 25, 1475-1482. [CrossRef]

119. Suwińska, A.; Wasag, P.; Zakrzewski, P.; Lenartowska, M.; Lenartowski, R. Calreticulin is required for calcium homeostasis and proper pollen tube tip growth in Petunia. Planta 2017, 245, 909-926. [CrossRef]

120. Wang, S.-S.; Diao, W.-Z.; Yang, X.; Qiao, Z.; Wang, M.; Acharya, B.R.; Zhang, W. Arabidopsis thaliana CML25 mediates the $\mathrm{Ca}(2+)$ regulation of $\mathrm{K}(+)$ transmembrane trafficking during pollen germination and tube elongation. Plant. Cell Environ. 2015, 38, 2372-2386. [CrossRef]

121. Yang, X.; Wang, S.-S.; Wang, M.; Qiao, Z.; Bao, C.-C.; Zhang, W. Arabidopsis thaliana calmodulin-like protein CML24 regulates pollen tube growth by modulating the actin cytoskeleton and controlling the cytosolic $\mathrm{Ca}(2+)$ concentration. Plant. Mol. Biol. 2014, 86, 225-236. [CrossRef] [PubMed] 
122. Qian, D.; Xiang, Y. Actin Cytoskeleton as Actor in Upstream and Downstream of Calcium Signaling in Plant Cells. Int. J. Mol. Sci. 2019, 20, 1403. [CrossRef] [PubMed]

123. Elliott, L.; Moore, I.; Kirchhelle, C. Spatio-temporal control of post-Golgi exocytic trafficking in plants. J. Cell. Sci. 2020, 133. [CrossRef] [PubMed]

124. Feiguelman, G.; Fu, Y.; Yalovsky, S. ROP GTPases Structure-Function and Signaling Pathways. Plant. Physiol. 2018, 176, 57-79. [CrossRef] [PubMed]

125. Bourne, H.R.; Sanders, D.A.; McCormick, F. The GTPase superfamily: Conserved structure and molecular mechanism. Nature 1991, 349, 117-127. [CrossRef]

126. Berken, A.; Thomas, C.; Wittinghofer, A. A new family of RhoGEFs activates the Rop molecular switch in plants. Nature 2005, 436, 1176-1180. [CrossRef]

127. Wu, G.; Li, H.; Yang, Z. Arabidopsis RopGAPs are a novel family of rho GTPase-activating proteins that require the Cdc42/Rac-interactive binding motif for rop-specific GTPase stimulation. Plant. Physiol. 2000, 124, 1625-1636. [CrossRef]

128. DerMardirossian, C.; Bokoch, G.M. GDIs: Central regulatory molecules in Rho GTPase activation. Trends Cell Biol. 2005, 15, 356-363. [CrossRef]

129. Bischoff, F.; Molendijk, A.; Rajendrakumar, C.S.V.; Palme, K. GTP-binding proteins in plants. Cell. Mol. Life Sci. CMLS 1999, 55, 233-256. [CrossRef]

130. Cheung, A.Y.; Chen, C.Y.-H.; Glaven, R.H.; de Graaf, B.H.J.; Vidali, L.; Hepler, P.K.; Wu, H. Rab2 GTPase regulates vesicle trafficking between the endoplasmic reticulum and the Golgi bodies and is important to pollen tube growth. Plant. Cell 2002, 14, 945-962. [CrossRef]

131. de Graaf, B.H.J.; Cheung, A.Y.; Andreyeva, T.; Levasseur, K.; Kieliszewski, M.; Wu, H. Rab11 GTPase-regulated membrane trafficking is crucial for tip-focused pollen tube growth in tobacco. Plant. Cell 2005, 17, 2564-2579. [CrossRef] [PubMed]

132. Szumlanski, A.L.; Nielsen, E. The Rab GTPase RabA4d regulates pollen tube tip growth in Arabidopsis thaliana. Plant. Cell 2009, 21, 526-544. [CrossRef]

133. Peng, J.; Ilarslan, H.; Wurtele, E.S.; Bassham, D.C. AtRabD2b and AtRabD2c have overlapping functions in pollen development and pollen tube growth. BMC Plant. Biol. 2011, 11, 25. [CrossRef] [PubMed]

134. Gutkowska, M.; Wnuk, M.; Nowakowska, J.; Lichocka, M.; Stronkowski, M.M.; Swiezewska, E. Rab geranylgeranyl transferase $\beta$ subunit is essential for male fertility and tip growth in Arabidopsis. J. Exp. Bot. 2015, 66, 213-224. [CrossRef]

135. Klahre, U.; Kost, B. Tobacco RhoGTPase ACTIVATING PROTEIN1 spatially restricts signaling of RAC/Rop to the apex of pollen tubes. Plant. Cell 2006, 18, 3033-3046. [CrossRef] [PubMed]

136. Kost, B. Spatial control of Rho (Rac-Rop) signaling in tip-growing plant cells. Trends Cell Biol. 2008, 18, 119-127. [CrossRef]

137. Bloch, D.; Pleskot, R.; Pejchar, P.; Potocký, M.; Trpkošová, P.; Cwiklik, L.; Vukašinović, N.; Sternberg, H.; Yalovsky, S.; Žárský, V. Exocyst SEC3 and phosphoinositides define sites of exocytosis in pollen tube initiation and growth. Plant. Physiol. 2016, 172, 980-1002. [CrossRef]

138. Lavy, M.; Bloch, D.; Hazak, O.; Gutman, I.; Poraty, L.; Sorek, N.; Sternberg, H.; Yalovsky, S. A Novel ROP/RAC effector links cell polarity, root-meristem maintenance, and vesicle trafficking. Curr. Biol. 2007, 17, 947-952. [CrossRef]

139. Li, S.; Gu, Y.; Yan, A.; Lord, E.; Yang, Z.-B. RIP1 (ROP Interactive Partner 1)/ICR1 marks pollen germination sites and may act in the ROP1 pathway in the control of polarized pollen growth. Mol. Plant. 2008, 1, 1021-1035. [CrossRef]

140. Chen, C.Y.-H.; Cheung, A.Y.; Wu, H. Actin-depolymerizing factor mediates Rac/Rop GTPase-regulated pollen tube growth. Plant. Cell 2003, 15, 237-249. [CrossRef]

141. Lee, Y.J.; Szumlanski, A.; Nielsen, E.; Yang, Z. Rho-GTPase-dependent filamentous actin dynamics coordinate vesicle targeting and exocytosis during tip growth. J. Cell Biol. 2008, 181, 1155-1168. [CrossRef]

142. Stephan, O.; Cottier, S.; Fahlén, S.; Montes-Rodriguez, A.; Sun, J.; Eklund, D.M.; Klahre, U.; Kost, B. RISAP is a TGN-associated RAC5 effector regulating membrane traffic during polar cell growth in tobacco. Plant. Cell 2014, 26, 4426-4447. [CrossRef] [PubMed]

143. Takeuchi, H.; Higashiyama, T. Tip-localized receptors control pollen tube growth and LURE sensing in Arabidopsis. Nature 2016, 531, 245-248. [CrossRef] [PubMed] 
144. Sugiyama, Y.; Nagashima, Y.; Wakazaki, M.; Sato, M.; Toyooka, K.; Fukuda, H.; Oda, Y. A Rho-actin signaling pathway shapes cell wall boundaries in Arabidopsis xylem vessels. Nat. Commun. 2019, 10, 468. [CrossRef] [PubMed]

145. Li, H.; Lin, Y.; Heath, R.M.; Zhu, M.X.; Yang, Z. Control of pollen tube tip growth by a Rop GTPase-dependent pathway that leads to tip-localized calcium influx. Plant. Cell 1999, 11, 1731-1742.

146. Winge, P.; Brembu, T.; Kristensen, R.; Bones, A.M. Genetic structure and evolution of RAC-GTPases in Arabidopsis thaliana. Genetics 2000, 156, 1959-1971.

147. Klahre, U.; Becker, C.; Schmitt, A.C.; Kost, B. Nt-RhoGDI2 regulates Rac/Rop signaling and polar cell growth in tobacco pollen tubes. Plant. J. 2006, 46, 1018-1031. [CrossRef]

148. Sun, J.; Eklund, D.M.; Montes-Rodriguez, A.; Kost, B. In vivo Rac/Rop localization as well as interaction with RhoGAP and RhoGDI in tobacco pollen tubes: Analysis by low-level expression of fluorescent fusion proteins and bimolecular fluorescence complementation. Plant J. 2015, 84, 83-98. [CrossRef]

149. Feng, Q.-N.; Kang, H.; Song, S.-J.; Ge, F.-R.; Zhang, Y.-L.; Li, E.; Li, S.; Zhang, Y. Arabidopsis RhoGDIs Are Critical for Cellular Homeostasis of Pollen Tubes. Plant. Physiol. 2016, 170, 841-856. [CrossRef]

150. Kim, E.-J.; Park, S.-W.; Hong, W.-J.; Silva, J.; Liang, W.; Zhang, D.; Jung, K.-H.; Kim, Y.-J. Genome-wide analysis of RopGEF gene family to identify genes contributing to pollen tube growth in rice (Oryza sativa). BMC Plant. Biol. 2020, 20, 95. [CrossRef]

151. Chang, F.; Gu, Y.; Ma, H.; Yang, Z. AtPRK2 promotes ROP1 activation via RopGEFs in the control of polarized pollen tube growth. Mol. Plant. 2013, 6, 1187-1201. [CrossRef] [PubMed]

152. Li, E.; Cui, Y.; Ge, F.-R.; Chai, S.; Zhang, W.-T.; Feng, Q.-N.; Jiang, L.; Li, S.; Zhang, Y. AGC1.5 Kinase Phosphorylates RopGEFs to Control Pollen Tube Growth. Mol. Plant. 2018, 11, 1198-1209. [CrossRef] [PubMed]

153. Higashiyama, T.; Yang, W.-C. Gametophytic Pollen Tube Guidance: Attractant Peptides, Gametic Controls, and Receptors. Plant. Physiol. 2017, 173, 112-121. [CrossRef] [PubMed]

154. Takeuchi, H.; Higashiyama, T. A Species-Specific Cluster of Defensin-Like Genes Encodes Diffusible Pollen Tube Attractants in Arabidopsis. PLoS Biol. 2012, 10, e1001449. [CrossRef] [PubMed]

155. Wang, T.; Liang, L.; Xue, Y.; Jia, P.-F.; Chen, W.; Zhang, M.-X.; Wang, Y.-C.; Li, H.-J.; Yang, W.-C. A receptor heteromer mediates the male perception of female attractants in plants. Nature 2016, 531, 241-244. [CrossRef]

156. Gu, Y.; Li, S.; Lord, E.M.; Yang, Z. Members of a novel class of Arabidopsis Rho guanine nucleotide exchange factors control Rho GTPase-dependent polar growth. Plant. Cell 2006, 18, 366-381. [CrossRef]

157. Meijer, H.J.G.; Munnik, T. PHOSPHOLIPID-BASED SIGNALING IN PLANTS. Ann. Rev. Plant. Biol. 2003, 54, 265-306. [CrossRef]

158. Noack, L.C.; Pejchar, P.; Sekereš, J.; Jaillais, Y.; Potocký, M. Transient Gene Expression as a Tool to Monitor and Manipulate the Levels of Acidic Phospholipids in Plant Cells. Methods Mol. Biol. 2019, 1992, 189-199. [CrossRef]

159. Collin, S.; Justin, A.M.; Cantrel, C.; Arondel, V.; Kader, J.C. Identification of AtPIS, a phosphatidylinositol synthase from Arabidopsis. Eur. J. Biochem. 1999, 262, 652-658. [CrossRef]

160. Löfke, C.; Ischebeck, T.; König, S.; Freitag, S.; Heilmann, I. Alternative metabolic fates of phosphatidylinositol produced by phosphatidylinositol synthase isoforms in Arabidopsis thaliana. Biochem. J. 2008, 413, 115-124. [CrossRef]

161. Ischebeck, T.; Vu, L.H.; Jin, X.; Stenzel, I.; Löfke, C.; Heilmann, I. Functional Cooperativity of Enzymes of Phosphoinositide Conversion According to Synergistic Effects on Pectin Secretion in Tobacco Pollen Tubes. Mol. Plant. 2010, 3, 870-881. [CrossRef] [PubMed]

162. Gerth, K.; Lin, F.; Menzel, W.; Krishnamoorthy, P.; Stenzel, I.; Heilmann, M.; Heilmann, I. Guilt by Association: A Phenotype-Based View of the Plant Phosphoinositide Network. Ann. Rev. Plant. Biol. 2017, 68, 349-374. [CrossRef] [PubMed]

163. Heilmann, I. Phosphoinositide signaling in plant development. Development 2016, 143, 2044-2055. [CrossRef] [PubMed]

164. Meijer, H.J.; Berrie, C.P.; Iurisci, C.; Divecha, N.; Musgrave, A.; Munnik, T. Identification of a new polyphosphoinositide in plants, phosphatidylinositol 5-monophosphate (PtdIns5P), and its accumulation upon osmotic stress. Biochem. J. 2001, 360, 491-498. [CrossRef] 
165. Krinke, O.; Ruelland, E.; Valentová, O.; Vergnolle, C.; Renou, J.-P.; Taconnat, L.; Flemr, M.; Burketová, L.; Zachowski, A. Phosphatidylinositol 4-Kinase Activation Is an Early Response to Salicylic Acid in Arabidopsis Suspension Cells. Plant. Physiol. 2007, 144, 1347-1359. [CrossRef] [PubMed]

166. Simon, M.L.A.; Platre, M.P.; Assil, S.; van Wijk, R.; Chen, W.Y.; Chory, J.; Dreux, M.; Munnik, T.; Jaillais, Y. A multi-colour/multi-affinity marker set to visualize phosphoinositide dynamics in Arabidopsis. Plant. J. 2014, 77, 322-337. [CrossRef] [PubMed]

167. Thole, J.M.; Vermeer, J.E.M.; Zhang, Y.; Gadella, T.W.J.; Nielsen, E. ROOT HAIR DEFECTIVE4 Encodes a Phosphatidylinositol-4-Phosphate Phosphatase Required for Proper Root Hair Development in Arabidopsis thaliana. Plant. Cell 2008, 20,381-395. [CrossRef]

168. Vermeer, J.E.M.; Thole, J.M.; Goedhart, J.; Nielsen, E.; Munnik, T.; Gadella, T.W.J. Imaging phosphatidylinositol 4-phosphate dynamics in living plant cells. Plant. J. 2009, 57, 356-372. [CrossRef]

169. Kang, B.-H.; Nielsen, E.; Preuss, M.L.; Mastronarde, D.; Staehelin, L.A. Electron tomography of RabA4b- and PI-4K $\beta 1$-labeled trans Golgi network compartments in Arabidopsis. Traffic 2011, 12, 313-329. [CrossRef]

170. Preuss, M.L.; Schmitz, A.J.; Thole, J.M.; Bonner, H.K.S.; Otegui, M.S.; Nielsen, E. A role for the RabA4b effector protein PI-4Kbeta1 in polarized expansion of root hair cells in Arabidopsis thaliana. J. Cell Biol. 2006, 172, 991-998. [CrossRef]

171. Jia, P.-F.; Xue, Y.; Li, H.-J.; Yang, W.-C. Golgi-localized LOT regulates trans-Golgi network biogenesis and pollen tube growth. Proc. Natl. Acad. Sci. USA 2018, 115, 12307-12312. [CrossRef]

172. Lin, F.; Krishnamoorthy, P.; Schubert, V.; Hause, G.; Heilmann, M.; Heilmann, I. A dual role for cell plate-associated PI4K $\beta$ in endocytosis and phragmoplast dynamics during plant somatic cytokinesis. Embo J. 2019, 38. [CrossRef] [PubMed]

173. Rubilar-Hernández, C.; Osorio-Navarro, C.; Cabello, F.; Norambuena, L. PI4KIII $\beta$ Activity Regulates Lateral Root Formation Driven by Endocytic Trafficking to the Vacuole. Plant. Physiol. 2019, 181, 112-126. [CrossRef] [PubMed]

174. Mueller-Roeber, B.; Pical, C. Inositol phospholipid metabolism in Arabidopsis. Characterized and putative isoforms of inositol phospholipid kinase and phosphoinositide-specific phospholipase C. Plant. Physiol. 2002, 130, 22-46. [CrossRef] [PubMed]

175. Strahl, T.; Hama, H.; DeWald, D.B.; Thorner, J. Yeast phosphatidylinositol 4-kinase, Pik1, has essential roles at the Golgi and in the nucleus. J. Cell Biol. 2005, 171, 967-979. [CrossRef] [PubMed]

176. Yoshida, S.; Ohya, Y.; Goebl, M.; Nakano, A.; Anraku, Y. A novel gene, STT4, encodes a phosphatidylinositol 4-kinase in the PKC1 protein kinase pathway of Saccharomyces cerevisiae. J. Biol. Chem. 1994, 269, 1166-1172. [PubMed]

177. Im, Y.J.; Davis, A.J.; Perera, I.Y.; Johannes, E.; Allen, N.S.; Boss, W.F. The N-terminal Membrane Occupation and Recognition Nexus Domain of Arabidopsis Phosphatidylinositol Phosphate Kinase 1 Regulates Enzyme Activity. J. Biol. Chem. 2007, 282, 5443-5452. [CrossRef]

178. Stenzel, I.; Ischebeck, T.; Quint, M.; Heilmann, I. Variable Regions of PI4P 5-Kinases Direct PtdIns(4,5)P2 Toward Alternative Regulatory Functions in Tobacco Pollen Tubes. Front. Plant. Sci. 2012, 2. [CrossRef]

179. Honys, D.; Twell, D. Transcriptome analysis of haploid male gametophyte development in Arabidopsis. Genome Biol. 2004, 5, R85. [CrossRef]

180. Wang, Y.; Zhang, W.-Z.; Song, L.-F.; Zou, J.-J.; Su, Z.; Wu, W.-H. Transcriptome Analyses Show Changes in Gene Expression to Accompany Pollen Germination and Tube Growth in Arabidopsis. Plant. Physiol. 2008, 148, 1201-1211. [CrossRef]

181. Ischebeck, T.; Stenzel, I.; Heilmann, I. Type B Phosphatidylinositol-4-Phosphate 5-Kinases Mediate Arabidopsis and Nicotiana tabacum Pollen Tube Growth by Regulating Apical Pectin Secretion. Plant Cell Online 2008, 20, 3312-3330. [CrossRef] [PubMed]

182. Grobei, M.A.; Qeli, E.; Brunner, E.; Rehrauer, H.; Zhang, R.; Roschitzki, B.; Basler, K.; Ahrens, C.H.; Grossniklaus, U. Deterministic protein inference for shotgun proteomics data provides new insights into Arabidopsis pollen development and function. Genome Res. 2009, 19, 1786-1800. [CrossRef] [PubMed]

183. Sousa, E.; Kost, B.; Malho, R. Arabidopsis Phosphatidylinositol-4-Monophosphate 5-Kinase 4 Regulates Pollen Tube Growth and Polarity by Modulating Membrane Recycling. Plant Cell Online 2008, 20, 3050-3064. [CrossRef] [PubMed] 
184. Zhao, Y.; Yan, A.; Feijó, J.A.; Furutani, M.; Takenawa, T.; Hwang, I.; Fu, Y.; Yang, Z. Phosphoinositides regulate clathrin-dependent endocytosis at the tip of pollen tubes in Arabidopsis and tobacco. Plant. Cell 2010, 22, 4031-4044. [CrossRef]

185. Dowd, P.E.; Coursol, S.; Skirpan, A.L.; Kao, T.; Gilroy, S. Petunia phospholipase c1 is involved in pollen tube growth. Plant. Cell 2006, 18, 1438-1453. [CrossRef]

186. Hempel, F.; Stenzel, I.; Heilmann, M.; Krishnamoorthy, P.; Menzel, W.; Golbik, R.; Helm, S.; Dobritzsch, D.; Baginsky, S.; Lee, J.; et al. MAPKs Influence Pollen Tube Growth by Controlling the Formation of Phosphatidylinositol 4,5-Bisphosphate in an Apical Plasma Membrane Domain. Plant. Cell 2017, 29, 3030-3050. [CrossRef]

187. Kaneda, M.; van Oostende-Triplet, C.; Chebli, Y.; Testerink, C.; Bednarek, S.Y.; Geitmann, A. Plant AP180 N-Terminal Homolog Proteins Are Involved in Clathrin-Dependent Endocytosis during Pollen Tube Growth in Arabidopsis thaliana. Plant. Cell Physiol. 2019, 60, 1316-1330. [CrossRef]

188. Kolay, S.; Basu, U.; Raghu, P. Control of diverse subcellular processes by a single multi-functional lipid phosphatidylinositol 4,5-bisphosphate [PI(4,5)P2]. Biochem. J. 2016, 473, 1681-1692. [CrossRef]

189. Mähs, A.; Ischebeck, T.; Heilig, Y.; Stenzel, I.; Hempel, F.; Seiler, S.; Heilmann, I. The essential phosphoinositide kinase MSS-4 is required for polar hyphal morphogenesis, localizing to sites of growth and cell fusion in Neurospora crassa. PLoS ONE 2012, 7, e51454. [CrossRef]

190. Raghu, P.; Joseph, A.; Krishnan, H.; Singh, P.; Saha, S. Phosphoinositides: Regulators of Nervous System Function in Health and Disease. Front. Mol. NeuroSci. 2019, 12, 208. [CrossRef]

191. Hille, B.; Dickson, E.J.; Kruse, M.; Vivas, O.; Suh, B.-C. Phosphoinositides regulate ion channels. Biochim. Biophys. Acta 2015, 1851, 844-856. [CrossRef] [PubMed]

192. Martin, T.F.J. Role of $\mathrm{PI}(4,5) \mathrm{P}(2)$ in vesicle exocytosis and membrane fusion. Subcell. Biochem. 2012, 59, 111-130. [CrossRef] [PubMed]

193. Wu, B.; Guo, W. The Exocyst at a Glance. J. Cell. Sci. 2015, 128, 2957-2964. [CrossRef] [PubMed]

194. Žárský, V.; Sekereš, J.; Kubátová, Z.; Pečenková, T.; Cvrčková, F. Three subfamilies of exocyst EXO70 family subunits in land plants: Early divergence and ongoing functional specialization. J. Exp. Bot. 2020, 71, 49-62. [CrossRef] [PubMed]

195. He, B.; Xi, F.; Zhang, X.; Zhang, J.; Guo, W. Exo70 interacts with phospholipids and mediates the targeting of the exocyst to the plasma membrane. Embo J. 2007, 26, 4053-4065. [CrossRef] [PubMed]

196. Guo, W.; Tamanoi, F.; Novick, P. Spatial regulation of the exocyst complex by Rho1 GTPase. Nat. Cell Biol. 2001, 3, 353-360. [CrossRef] [PubMed]

197. Zhang, X.; Orlando, K.; He, B.; Xi, F.; Zhang, J.; Zajac, A.; Guo, W. Membrane association and functional regulation of Sec3 by phospholipids and Cdc42. J. Cell Biol. 2008, 180, 145-158. [CrossRef]

198. Elias, M.; Drdova, E.; Ziak, D.; Bavlnka, B.; Hala, M.; Cvrckova, F.; Soukupova, H.; Zarsky, V. The exocyst complex in plants. Cell Biol. Int. 2003, 27, 199-201. [CrossRef]

199. Hála, M.; Cole, R.; Synek, L.; Drdová, E.; Pecenková, T.; Nordheim, A.; Lamkemeyer, T.; Madlung, J.; Hochholdinger, F.; Fowler, J.E.; et al. An exocyst complex functions in plant cell growth in Arabidopsis and tobacco. Plant. Cell 2008, 20, 1330-1345. [CrossRef]

200. TerBush, D.R.; Maurice, T.; Roth, D.; Novick, P. The Exocyst is a multiprotein complex required for exocytosis in Saccharomyces cerevisiae. Embo J. 1996, 15, 6483-6494. [CrossRef]

201. Dubuke, M.L.; Maniatis, S.; Shaffer, S.A.; Munson, M. The Exocyst Subunit Sec6 Interacts with Assembled Exocytic SNARE Complexes. J. Biol. Chem. 2015, 290, 28245-28256. [CrossRef] [PubMed]

202. Guo, W.; Roth, D.; Walch-Solimena, C.; Novick, P. The exocyst is an effector for Sec4p, targeting secretory vesicles to sites of exocytosis. Embo J. 1999, 18, 1071-1080. [CrossRef] [PubMed]

203. Pleskot, R.; Cwiklik, L.; Jungwirth, P.; Žárský, V.; Potocký, M. Membrane targeting of the yeast exocyst complex. Biochim. Biophys. Acta 2015, 1848, 1481-1489. [CrossRef] [PubMed]

204. Synek, L.; Schlager, N.; Eliás, M.; Quentin, M.; Hauser, M.-T.; Zárský, V. AtEXO70A1, a member of a family of putative exocyst subunits specifically expanded in land plants, is important for polar growth and plant development. Plant. J. 2006, 48, 54-72. [CrossRef]

205. Yue, P.; Zhang, Y.; Mei, K.; Wang, S.; Lesigang, J.; Zhu, Y.; Dong, G.; Guo, W. Sec3 promotes the initial binary t-SNARE complex assembly and membrane fusion. Nat. Commun. 2017, 8, 14236. [CrossRef] [PubMed] 
206. Cole, R.A.; Synek, L.; Zarsky, V.; Fowler, J.E. SEC8, a subunit of the putative Arabidopsis exocyst complex, facilitates pollen germination and competitive pollen tube growth. Plant. Physiol. 2005, 138, 2005-2018. [CrossRef]

207. Synek, L.; Vukašinović, N.; Kulich, I.; Hála, M.; Aldorfová, K.; Fendrych, M.; Žárský, V. EXO70C2 Is a Key Regulatory Factor for Optimal Tip Growth of Pollen. Plant. Physiol. 2017, 174, 223-240. [CrossRef]

208. Li, Y.; Tan, X.; Wang, M.; Li, B.; Zhao, Y.; Wu, C.; Rui, Q.; Wang, J.; Liu, Z.; Bao, Y. Exocyst subunit SEC3A marks the germination site and is essential for pollen germination in Arabidopsis thaliana. Sci. Rep. 2017, 7 , 40279. [CrossRef]

209. Zárský, V.; Kulich, I.; Fendrych, M.; Pečenková, T. Exocyst complexes multiple functions in plant cells secretory pathways. Curr. Opin. Plant. Biol. 2013, 16, 726-733. [CrossRef]

210. Fendrych, M.; Synek, L.; Pecenková, T.; Toupalová, H.; Cole, R.; Drdová, E.; Nebesárová, J.; Sedinová, M.; Hála, M.; Fowler, J.E.; et al. The Arabidopsis exocyst complex is involved in cytokinesis and cell plate maturation. Plant. Cell 2010, 22, 3053-3065. [CrossRef]

211. Pecenková, T.; Markovic, V.; Sabol, P.; Kulich, I.; Žárský, V. Exocyst and autophagy-related membrane trafficking in plants. J. Exp. Bot. 2017, 69, 47-57. [CrossRef] [PubMed]

212. Sabol, P.; Kulich, I.; Žárský, V. RIN4 recruits the exocyst subunit EXO70B1 to the plasma membrane. J. Exp. Bot. 2017, 68, 3253-3265. [CrossRef] [PubMed]

213. Stegmann, M.; Anderson, R.G.; Ichimura, K.; Pecenkova, T.; Reuter, P.; Žársky, V.; McDowell, J.M.; Shirasu, K.; Trujillo, M. The ubiquitin ligase PUB22 targets a subunit of the exocyst complex required for PAMP-triggered responses in Arabidopsis. Plant. Cell 2012, 24, 4703-4716. [CrossRef] [PubMed]

214. Kubátová, Z.; Pejchar, P.; Potocký, M.; Sekereš, J.; Žárský, V.; Kulich, I. Arabidopsis Trichome Contains Two Plasma Membrane Domains with Different Lipid Compositions Which Attract Distinct EXO70 Subunits. Int. J. Mol. Sci. 2019, 20, 3803. [CrossRef]

215. Sekereš, J.; Pejchar, P.; Šantrůček, J.; Vukašinović, N.; Žárský, V.; Potocký, M. Analysis of Exocyst Subunit EXO70 Family Reveals Distinct Membrane Polar Domains in Tobacco Pollen Tubes. Plant. Physiol. 2017, 173, 1659-1675. [CrossRef]

216. Li, S.; van Os, G.M.A.; Ren, S.; Yu, D.; Ketelaar, T.; Emons, A.M.C.; Liu, C.-M. Expression and functional analyses of EXO70 genes in Arabidopsis implicate their roles in regulating cell type-specific exocytosis. Plant. Physiol. 2010, 154, 1819-1830. [CrossRef]

217. Pecenková, T.; Hála, M.; Kulich, I.; Kocourková, D.; Drdová, E.; Fendrych, M.; Toupalová, H.; Zársky, V. The role for the exocyst complex subunits Exo70B2 and Exo70H1 in the plant-pathogen interaction. J. Exp. Bot. 2011, 62, 2107-2116. [CrossRef]

218. Boyd, C.; Hughes, T.; Pypaert, M.; Novick, P. Vesicles carry most exocyst subunits to exocytic sites marked by the remaining two subunits, Sec3p and Exo70p. J. Cell Biol. 2004, 167, 889-901. [CrossRef]

219. Fendrych, M.; Synek, L.; Pecenková, T.; Drdová, E.J.; Sekeres, J.; de Rycke, R.; Nowack, M.K.; Zársky, V. Visualization of the exocyst complex dynamics at the plasma membrane of Arabidopsis thaliana. Mol. Biol. Cell 2013, 24, 510-520. [CrossRef]

220. Zhong, R.; Ye, Z.-H. The SAC Domain-Containing Protein Gene Family in Arabidopsis. Plant. Physiol. 2003, 132, 544-555. [CrossRef]

221. Despres, B.; Bouissonnie, F.; Wu, H.-J.; Gomord, V.; Guilleminot, J.; Grellet, F.; Berger, F.; Delseny, M.; Devic, M. Three SAC1-like genes show overlapping patterns of expression in Arabidopsis but are remarkably silent during embryo development. Plant. J. 2003, 34, 293-306. [CrossRef]

222. Ton, J.; Jakab, G.; Toquin, V.; Flors, V.; Iavicoli, A.; Maeder, M.N.; Métraux, J.-P.; Mauch-Mani, B. Dissecting the beta-aminobutyric acid-induced priming phenomenon in Arabidopsis. Plant. Cell 2005, 17, 987-999. [CrossRef] [PubMed]

223. Guo, T.; Chen, H.-C.; Lu, Z.-Q.; Diao, M.; Chen, K.; Dong, N.-Q.; Shan, J.-X.; Ye, W.-W.; Huang, S.; Lin, H.-X. A SAC Phosphoinositide Phosphatase Controls Rice Development via Hydrolyzing PI4P and PI $(4,5)$ P2. Plant. Physiol. 2020, 182, 1346-1358. [CrossRef] [PubMed]

224. Williams, M.E.; Torabinejad, J.; Cohick, E.; Parker, K.; Drake, E.J.; Thompson, J.E.; Hortter, M.; Dewald, D.B. Mutations in the Arabidopsis phosphoinositide phosphatase gene SAC9 lead to overaccumulation of PtdIns(4,5)P2 and constitutive expression of the stress-response pathway. Plant. Physiol. 2005, 138, 686-700. [CrossRef] 
225. Vollmer, A.H.; Youssef, N.N.; DeWald, D.B. Unique cell wall abnormalities in the putative phosphoinositide phosphatase mutant AtSAC9. Planta 2011, 234, 993-1005. [CrossRef] [PubMed]

226. Zhang, Z.; Li, Y.; Luo, Z.; Kong, S.; Zhao, Y.; Zhang, C.; Zhang, W.; Yuan, H.; Cheng, L. Expansion and Functional Divergence of Inositol Polyphosphate 5-Phosphatases in Angiosperms. Genes (Basel) 2019, 10, 393. [CrossRef]

227. Berdy, S.E.; Kudla, J.; Gruissem, W.; Gillaspy, G.E. Molecular characterization of At5PTase1, an inositol phosphatase capable of terminating inositol trisphosphate signaling. Plant. Physiol. 2001, 126, 801-810. [CrossRef]

228. Jones, M.A.; Raymond, M.J.; Smirnoff, N. Analysis of the root-hair morphogenesis transcriptome reveals the molecular identity of six genes with roles in root-hair development in Arabidopsis. Plant. J. 2006, 45, 83-100. [CrossRef]

229. Ringli, C.; Baumberger, N.; Keller, B. The Arabidopsis root hair mutants der2-der9 are affected at different stages of root hair development. Plant. Cell Physiol. 2005, 46, 1046-1053. [CrossRef]

230. Zhong, R.; Ye, Z.-H. Molecular and biochemical characterization of three WD-repeat-domain-containing inositol polyphosphate 5-phosphatases in Arabidopsis thaliana. Plant. Cell Physiol. 2004, 45, 1720-1728. [CrossRef]

231. Hanahan, D.J.; Chaikoff, I.L. A new phospholipide-splitting enzyme specific for the ester linkage between the nitrogenous base and the phosphoric acid grouping. J. Biol. Chem. 1947, 169, 699-705. [PubMed]

232. Irvine, R.F.; Letcher, A.J.; Dawson, R.M. Phosphatidylinositol phosphodiesterase in higher plants. Biochem. J. 1980, 192, 279-283. [CrossRef] [PubMed]

233. Wang, G.; Ryu, S.; Wang, X. Plant Phospholipases: An Overview. In Lipases and Phospholipases; Sandoval, G., Ed.; Humana Press: Totowa, NJ, USA, 2012; Volume 861, pp. 123-137. ISBN 978-1-61779-599-2.

234. Pokotylo, I.; Pejchar, P.; Potocký, M.; Kocourková, D.; Krčková, Z.; Ruelland, E.; Kravets, V.; Martinec, J. The plant non-specific phospholipase $\mathrm{C}$ gene family. Novel competitors in lipid signalling. Prog. Lipid Res. 2013, 52, 62-79. [CrossRef]

235. Pokotylo, I.; Kolesnikov, Y.; Kravets, V.; Zachowski, A.; Ruelland, E. Plant phosphoinositide-dependent phospholipases C: Variations around a canonical theme. Biochimie 2014, 96, 144-157. [CrossRef] [PubMed]

236. Ngo, A.H.; Lin, Y.-C.; Liu, Y.-C.; Gutbrod, K.; Peisker, H.; Dörmann, P.; Nakamura, Y. A pair of nonspecific phospholipases C, NPC2 and NPC6, are involved in gametophyte development and glycerolipid metabolism in Arabidopsis. New Phytol. 2018, 219, 163-175. [CrossRef]

237. Ngo, A.H.; Kanehara, K.; Nakamura, Y. Non-specific phospholipases C, NPC2 and NPC6, are required for root growth in Arabidopsis. Plant. J. 2019, 100, 825-835. [CrossRef]

238. Wimalasekera, R.; Pejchar, P.; Holk, A.; Martinec, J.; Scherer, G.F.E. Plant phosphatidylcholine-hydrolyzing phospholipases C NPC3 and NPC4 with roles in root development and brassinolide signaling in Arabidopsis thaliana. Mol. Plant. 2010, 3, 610-625. [CrossRef]

239. Helling, D.; Possart, A.; Cottier, S.; Klahre, U.; Kost, B. Pollen tube tip growth depends on plasma membrane polarization mediated by tobacco PLC3 activity and endocytic membrane recycling. Plant. Cell 2006, 18, 3519-3534. [CrossRef]

240. Stenzel, I.; Ischebeck, T.; Vu-Becker, L.H.; Riechmann, M.; Krishnamoorthy, P.; Fratini, M.; Heilmann, I. Coordinated Localization and Antagonistic Function of NtPLC3 and PI4P 5-Kinases in the Subapical Plasma Membrane of Tobacco Pollen Tubes. Plants 2020, 9, 452. [CrossRef]

241. Hokin, L.E. Receptors and phosphoinositide-generated second messengers. Ann. Rev. Biochem. 1985, 54, 205-235. [CrossRef]

242. Munnik, T.; Testerink, C. Plant phospholipid signaling: "in a nutshell”. J. Lipid Res. 2009, 50, S260-S265. [CrossRef] [PubMed]

243. Hong, Y.; Zhao, J.; Guo, L.; Kim, S.-C.; Deng, X.; Wang, G.; Zhang, G.; Li, M.; Wang, X. Plant phospholipases $\mathrm{D}$ and $\mathrm{C}$ and their diverse functions in stress responses. Prog. Lipid Res. 2016, 62, 55-74. [CrossRef]

244. Lorenzo-Orts, L.; Couto, D.; Hothorn, M. Identity and functions of inorganic and inositol polyphosphates in plants. New Phytol. 2020, 225, 637-652. [CrossRef] [PubMed]

245. Tsui, M.M.; York, J.D. Roles of inositol phosphates and inositol pyrophosphates in development, cell signaling and nuclear processes. Adv. Enzym. Regul. 2010, 50, 324-337. [CrossRef] [PubMed] 
246. Calderón Villalobos, L.I.A.; Lee, S.; De Oliveira, C.; Ivetac, A.; Brandt, W.; Armitage, L.; Sheard, L.B.; Tan, X.; Parry, G.; Mao, H.; et al. A combinatorial TIR1/AFB-Aux/IAA co-receptor system for differential sensing of auxin. Nat. Chem. Biol. 2012, 8, 477-485. [CrossRef] [PubMed]

247. Laha, D.; Parvin, N.; Dynowski, M.; Johnen, P.; Mao, H.; Bitters, S.T.; Zheng, N.; Schaaf, G. Inositol Polyphosphate Binding Specificity of the Jasmonate Receptor Complex. Plant. Physiol. 2016, 171, 2364-2370. [CrossRef] [PubMed]

248. Mosblech, A.; Thurow, C.; Gatz, C.; Feussner, I.; Heilmann, I. Jasmonic acid perception by COI1 involves inositol polyphosphates in Arabidopsis thaliana. Plant. J. 2011, 65, 949-957. [CrossRef]

249. Sheard, L.B.; Tan, X.; Mao, H.; Withers, J.; Ben-Nissan, G.; Hinds, T.R.; Kobayashi, Y.; Hsu, F.-F.; Sharon, M.; Browse, J.; et al. Jasmonate perception by inositol-phosphate-potentiated COI1-JAZ co-receptor. Nature 2010, 468, 400-405. [CrossRef]

250. Tan, X.; Calderon-Villalobos, L.I.A.; Sharon, M.; Zheng, C.; Robinson, C.V.; Estelle, M.; Zheng, N. Mechanism of auxin perception by the TIR1 ubiquitin ligase. Nature 2007, 446, 640-645. [CrossRef]

251. Muradoğlu, F.; Yıldız, K.; Balta, F. Methyl jasmonate influences of pollen germination and pollen tube growth of apricot (Prunus armeniaca L.). Yüzüncü Yıl Univ. J. Agr. Sci. (Turk.) 2010, 183-188.

252. Gao, C.; Wang, Y.; Qu, H. Study of auxin regulation of pollen tube growth through calcium channels in Pyrus pyrifolia. Plant. Growth Regul. 2019, 89, 99-108. [CrossRef]

253. Zhan, H.; Zhong, Y.; Yang, Z.; Xia, H. Enzyme activities of Arabidopsis inositol polyphosphate kinases AtIPK $2 \alpha$ and AtIPK2 $\beta$ are involved in pollen development, pollen tube guidance and embryogenesis. Plant. J. 2015, 82, 758-771. [CrossRef]

254. Nishizuka, Y. The molecular heterogeneity of protein kinase $C$ and its implications for cellular regulation. Nature 1988, 334, 661-665. [CrossRef] [PubMed]

255. Valverde, A.M.; Sinnett-Smith, J.; Van Lint, J.; Rozengurt, E. Molecular cloning and characterization of protein kinase D: A target for diacylglycerol and phorbol esters with a distinctive catalytic domain. Proc. Natl. Acad. Sci. USA 1994, 91, 8572-8576. [CrossRef] [PubMed]

256. Islas-Flores, T.; Rahman, A.; Ullah, H.; Villanueva, M.A. The Receptor for Activated C Kinase in Plant Signaling: Tale of a Promiscuous Little Molecule. Front. Plant. Sci. 2015, 6. [CrossRef] [PubMed]

257. Arisz, S.A.; Testerink, C.; Munnik, T. Plant PA signaling via diacylglycerol kinase. Biochim. Biophys. Acta (BBA) Mol. Cell Biol. Lipids 2009, 1791, 869-875. [CrossRef] [PubMed]

258. Dong, W.; Lv, H.; Xia, G.; Wang, M. Does diacylglycerol serve as a signaling molecule in plants? Plant. Signal. Behav. 2012, 7, 472-475. [CrossRef] [PubMed]

259. Peters, C.; Kim, S.-C.; Devaiah, S.; Li, M.; Wang, X. Non-specific phospholipase C5 and diacylglycerol promote lateral root development under mild salt stress in Arabidopsis. Plant. Cell Environ. 2014, 37, 2002-2013. [CrossRef]

260. Potocký, M.; Pleskot, R.; Pejchar, P.; Vitale, N.; Kost, B.; Žárský, V. Live-cell imaging of phosphatidic acid dynamics in pollen tubes visualized by Spo20p-derived biosensor. New Phytol. 2014, 203, 483-494. [CrossRef]

261. Wissing, J.; Heim, S.; Wagner, K.G. Diacylglycerol kinase from suspension cultured plant cells: Purification and properties. Plant. Physiol. 1989, 90, 1546-1551. [CrossRef]

262. Pleskot, R.; Pejchar, P.; Bezvoda, R.; Lichtscheidl, I.; Wolters-Arts, M.; Marc, J.; Žárský, V.; Potocký, M. Turnover of Phosphatidic Acid through Distinct Signaling Pathways Affects Multiple Aspects of Pollen Tube Growth in Tobacco. Front. Plant. Sci. 2012, 3, 54. [CrossRef]

263. Ischebeck, T.; Valledor, L.; Lyon, D.; Gingl, S.; Nagler, M.; Meijón, M.; Egelhofer, V.; Weckwerth, W. Comprehensive cell-specific protein analysis in early and late pollen development from diploid microsporocytes to pollen tube growth. Mol. Cell Proteom. 2014, 13, 295-310. [CrossRef] [PubMed]

264. Vaz Dias, F.; Serrazina, S.; Vitorino, M.; Marchese, D.; Heilmann, I.; Godinho, M.; Rodrigues, M.; Malhó, R. A role for diacylglycerol kinase 4 in signalling crosstalk during Arabidopsis pollen tube growth. New Phytol. 2019. [CrossRef] [PubMed]

265. Wong, A.; Donaldson, L.; Portes, M.T.; Eppinger, J.; Feijó, J.; Gehring, C. The Arabidopsis Diacylglycerol Kinase 4 is involved in nitric oxide-dependent pollen tube guidance and fertilization. Development 2020. [CrossRef]

266. Angkawijaya, A.E.; Nguyen, V.C.; Gunawan, F.; Nakamura, Y. A Pair of Arabidopsis Diacylglycerol Kinases Essential for Gametogenesis and ER Phospholipid Metabolism in Leaves and Flowers. Plant. Cell 2020. [CrossRef] [PubMed] 
267. Eliáš, M.; Potocký, M.; Cvrčková, F.; Žárský, V. Molecular diversity of phospholipase D in angiosperms. BMC Genom. 2002, 3, 2. [CrossRef] [PubMed]

268. Li, J.; Wang, X. Phospholipase D and phosphatidic acid in plant immunity. Plant. Sci. 2019, 279, 45-50. [CrossRef] [PubMed]

269. Testerink, C.; Munnik, T. Phosphatidic acid: A multifunctional stress signaling lipid in plants. Trends Plant. Sci. 2005, 10, 368-375. [CrossRef] [PubMed]

270. Potocký, M.; Eliás, M.; Profotová, B.; Novotná, Z.; Valentová, O.; Zárský, V. Phosphatidic acid produced by phospholipase D is required for tobacco pollen tube growth. Planta 2003, 217, 122-130. [CrossRef]

271. Baneux, C.; Tanguy, E.; Thahouly, T.; Vitale, A.; Chasserot-Golaz, S.; Bader, M.-F.; Gasman, S.; Vitale, N. Phosphatidic acid metabolism regulates neuroendocrine secretion but is not under the direct control of lipins. Iubmb Life 2020, 72, 533-543. [CrossRef]

272. Tanguy, E.; Wang, Q.; Vitale, N. Role of Phospholipase D-Derived Phosphatidic Acid in Regulated Exocytosis and Neurological Disease. Handb Exp Pharm. 2020, 259, 115-130. [CrossRef]

273. Wang, H.; Zhang, C.; Xiao, H. Mechanism of membrane fusion: Protein-protein interaction and beyond. Int. J. Physiol. Pathophysiol. Pharm. 2019, 11, 250-257.

274. Noack, L.C.; Jaillais, Y. Functions of Anionic Lipids in Plants. Ann. Rev. Plant. Biol. 2020, 71, 71-102. [CrossRef] [PubMed]

275. Pleskot, R.; Potocký, M.; Pejchar, P.; Linek, J.; Bezvoda, R.; Martinec, J.; Valentová, O.; Novotná, Z.; Žárský, V. Mutual regulation of plant phospholipase $\mathrm{D}$ and the actin cytoskeleton: Reciprocal regulation of plant PLD and actin. Plant. J. 2010, 62, 494-507. [CrossRef]

276. Pejchar, P.; Sekereš, J.; Novotný, O.; Žárský, V.; Potocký, M. Functional analysis of phospholipase D $\delta$ family in tobacco pollen tubes. Plant. J. 2020. [CrossRef] [PubMed]

(C) 2020 by the authors. Licensee MDPI, Basel, Switzerland. This article is an open access article distributed under the terms and conditions of the Creative Commons Attribution (CC BY) license (http://creativecommons.org/licenses/by/4.0/). 